\title{
Improved Mechanistic Model of the Atmospheric Redox Chemistry of Mercury
}

Viral Shah,* Daniel J. Jacob, Colin P. Thackray, Xuan Wang, Elsie M. Sunderland, Theodore S. Dibble, Alfonso Saiz-Lopez, Ivan Cernusák, Vladimir Kellö, Pedro J. Castro, Rongrong Wu, and Chuji Wang

Cite This: Environ. Sci. Technol. 2021, 55, 14445-14456

Read Online

\section{ACCESS |}

Wlll Metrics \& More

Article Recommendations

Supporting Information

ABSTRACT: We present a new chemical mechanism for $\mathrm{Hg}^{0} / \mathrm{Hg}^{\mathrm{I}} / \mathrm{Hg}^{\mathrm{II}}$ atmospheric cycling, including recent laboratory and computational data, and implement it in the GEOS-Chem global atmospheric chemistry model for comparison to observations. Our mechanism includes the oxidation of $\mathrm{Hg}^{0}$ by $\mathrm{Br}$ and $\mathrm{OH}$, subsequent oxidation of $\mathrm{Hg}^{\mathrm{I}}$ by ozone and radicals, respeciation of $\mathrm{Hg}^{\mathrm{II}}$ in aerosols and cloud droplets, and speciated $\mathrm{Hg}^{\mathrm{II}}$ photolysis in the gas and aqueous phases. The tropospheric $\mathrm{Hg}$ lifetime against deposition in the model is 5.5 months, consistent with observational constraints. The model reproduces the observed global surface $\mathrm{Hg}^{0}$ concentrations and $\mathrm{Hg}^{\mathrm{II}}$ wet deposition fluxes. $\mathrm{Br}$ and $\mathrm{OH}$ make comparable contributions to global net oxidation of $\mathrm{Hg}^{0}$ to $\mathrm{Hg}^{\mathrm{II}}$.

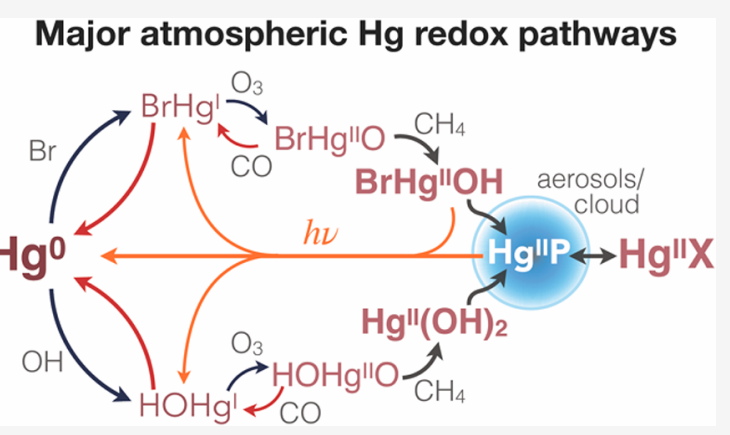
Ozone is the principal $\mathrm{Hg}^{\mathrm{I}}$ oxidant, enabling the efficient oxidation of $\mathrm{Hg}^{0}$ to $\mathrm{Hg}^{\mathrm{II}}$ by $\mathrm{OH}$. $\mathrm{BrHg}^{\mathrm{II}} \mathrm{OH}$ and $\mathrm{Hg}^{\mathrm{II}}(\mathrm{OH})_{2}$, the initial $\mathrm{Hg}^{\mathrm{II}}$ products of $\mathrm{Hg}^{0}$ oxidation, respeciate in aerosols and clouds to organic and inorganic complexes, and volatilize to photostable forms. Reduction of $\mathrm{Hg}^{\mathrm{II}}$ to $\mathrm{Hg}^{0}$ takes place largely through photolysis of aqueous $\mathrm{Hg}^{\mathrm{II}}$-organic complexes. $71 \%$ of model $\mathrm{Hg}^{\mathrm{II}}$ deposition is to the oceans. Major uncertainties for atmospheric $\mathrm{Hg}$ chemistry modeling include $\mathrm{Br}$ concentrations, stability and reactions of $\mathrm{Hg}^{\mathrm{I}}$, and speciation and photoreduction of $\mathrm{Hg}^{\mathrm{II}}$ in aerosols and clouds.

KEYWORDS: mercury modeling, chemical mechanism, mercury oxidation, mercury photoreduction, atmospheric lifetime, mercury deposition

\section{INTRODUCTION}

Mercury $(\mathrm{Hg})$ is an ecosystem pollutant transported globally through the atmosphere. It is emitted in gaseous elemental state $\left(\mathrm{Hg}^{0}\right)$ by natural and anthropogenic sources, and cycles in the atmosphere with divalent $\left(\mathrm{Hg}^{\mathrm{II}}\right)$ compounds that are highly water-soluble and rapidly deposited. Recent theoretical calculations show fast gas-phase reduction of the major $\mathrm{Hg}^{\mathrm{II}}$ species thought to be produced in the atmosphere, ${ }^{1-4}$ posing a challenge for atmospheric models to reproduce the atmospheric $\mathrm{Hg}$ concentrations and lifetime inferred from observations. ${ }^{5}$ At the same time, new oxidation pathways to form $\mathrm{Hg}^{\mathrm{II}}$ in the atmosphere have been proposed. ${ }^{5,6}$ Here, we integrate these recent developments into a new chemical mechanism for atmospheric models to shed new light on the redox cycling of atmospheric $\mathrm{Hg}$.

$\mathrm{Hg}^{0}$ is emitted to the atmosphere by mining, fuel combustion, and volcanism, and by volatilization of previously deposited $\mathrm{Hg}^{7,8}$ The $\mathrm{Hg}^{0}$ oxidation pathways and the speciation of $\mathrm{Hg}^{\mathrm{II}}$ remain highly uncertain. ${ }^{9-11}$ The $\mathrm{Br}$ atom is considered to be a major $\mathrm{Hg}^{0}$ oxidant. ${ }^{12-15}$ The oxidation of $\mathrm{Hg}^{0}$ to $\mathrm{Hg}^{\mathrm{II}}$ by $\mathrm{Br}$ takes place in two steps, beginning with the formation of $\mathrm{B} \mathrm{BrHg}^{\mathrm{I}}$ intermediate that then undergoes further oxidation to $\mathrm{Hg}^{\mathrm{II}} \cdot{ }^{16-18} \mathrm{NO}_{2}$ and $\mathrm{HO}_{2}$ have been thought to be the main $\mathrm{BrHg}^{\mathrm{I}}$ oxidants, ${ }^{19}$ but the $\mathrm{BrHg}^{\mathrm{II}} \mathrm{ONO}$ and
$\mathrm{BrHg}^{\mathrm{II}} \mathrm{OOH}$ products are rapidly photolyzed. ${ }^{1}$ Preliminary theoretical calculations by Saiz-Lopez et al. ${ }^{5}$ show that $\mathrm{BrHg}^{\mathrm{I}}$ may react rapidly with ozone to produce a $\mathrm{BrHg}^{\mathrm{II}} \mathrm{O}$ radical, which can then be stabilized to nonradical $\mathrm{Hg}^{\mathrm{II}}$ forms by subsequent reactions. ${ }^{2-4,20}$

The oxidation of $\mathrm{Hg}^{0}$ by $\mathrm{OH}$ has been included in many models, $^{21-24}$ but its atmospheric relevance has been questioned because of the low stability of $\mathrm{HOHg}^{\mathrm{I}} \cdot{ }^{17,25}$ Dibble et al. $^{6}$ recalculated the stability of $\mathrm{HOHg}^{\mathrm{I}}$ and found the $\mathrm{OH}$ initiated oxidation pathway to be potentially more important than previously thought. Oxidation of $\mathrm{Hg}^{0}$ by ozone $\mathrm{e}^{26,27}$ and $\mathrm{BrO}^{28}$ has been observed in the laboratory, but is not expected to be atmospherically relevant because the putative product $\left(\mathrm{Hg}^{\mathrm{II}} \mathrm{O}\right)$ is weakly bound in the gas phase. ${ }^{29-31}$ Oxidation of $\mathrm{Hg}^{0}$ by the $\mathrm{Cl}$ atom is fast and the $\mathrm{ClHg}^{\mathrm{I}}$ product is strongly bound, ${ }^{32}$ but the importance of this pathway is limited by the low $\mathrm{Cl}$ atom concentrations in the troposphere. ${ }^{33,34}$ Other

Special Issue: Tribute to James J. Morgan

Received: May 24, 2021

Revised: July 23, 2021

Accepted: July 23, 2021

Published: August 17, 2021

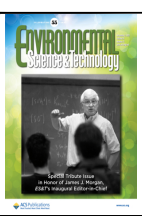


Table 1a. Chemical Mechanism: Bimolecular and Three-Body Reactions

\begin{tabular}{|c|c|c|}
\hline reaction & rate coefficients ${ }^{a}$ & references \\
\hline $\mathrm{Hg}^{0}+\mathrm{Br}+\mathrm{M} \rightarrow \mathrm{BrHg}^{\mathrm{I}}+\mathrm{M}$ & $k_{0}=1.46 \times 10^{-32}(T / 298)^{-1.86}$ & 45 \\
\hline $\mathrm{BrHg}^{\mathrm{I}}+\mathrm{M} \rightarrow \mathrm{Hg}^{0}+\mathrm{Br}+\mathrm{M}$ & $k_{0} / K_{\text {eq }} ; K_{\text {eq }}=9.14 \times 10^{-24} \exp (7801 / T)$ & 19 \\
\hline $\mathrm{Hg}^{0}+\mathrm{OH}+\mathrm{M} \rightarrow \mathrm{HOHg}^{\mathrm{I}}+\mathrm{M}$ & $k_{0}=3.34 \times 10^{-33} \exp (43 / T)$ & $55^{b}$ \\
\hline $\mathrm{HOHg}^{\mathrm{I}}+\mathrm{M} \rightarrow \mathrm{Hg}^{0}+\mathrm{OH}+\mathrm{M}$ & $k_{0} / K_{\text {eq }} ; K_{\text {eq }}=2.74 \times 10^{-24} \exp (5770 / T)$ & 6 \\
\hline $\mathrm{Hg}^{0}+\mathrm{Cl}+\mathrm{M} \rightarrow \mathrm{ClHg}^{\mathrm{I}}+\mathrm{M}$ & $k_{0}=2.25 \times 10^{-33} \exp (680 / T)$ & 32 \\
\hline $\mathrm{YHg}^{\mathrm{I}}+\mathrm{O}_{3} \rightarrow \mathrm{YHg}^{\mathrm{II}} \mathrm{O}+\mathrm{O}_{2}(Y \equiv \mathrm{Br}, \mathrm{OH}, \mathrm{Cl})$ & $3.0 \times 10^{-11}$ & $5^{c, d}$ \\
\hline $\mathrm{YHg}^{\mathrm{II}} \mathrm{O}+\mathrm{CH}_{4} \rightarrow \mathrm{YHg}^{\mathrm{II}} \mathrm{OH}+\mathrm{CH}_{3}(Y \equiv \mathrm{Br}, \mathrm{OH}, \mathrm{Cl})$ & $4.1 \times 10^{-12} \exp (-856 / T)$ & $2^{d}$ \\
\hline $\mathrm{YHg}^{\mathrm{II}} \mathrm{O}+\mathrm{CO} \rightarrow \mathrm{YHg}^{\mathrm{I}}+\mathrm{CO}_{2}(Y \equiv \mathrm{Br}, \mathrm{OH}, \mathrm{Cl})$ & $6.0 \times 10^{-11} \exp (-550 / T)$ & $4^{d, e}$ \\
\hline $\mathrm{YHg}^{\mathrm{I}}+\mathrm{NO}_{2}+\mathrm{M} \rightarrow \mathrm{YHg}^{\mathrm{II}} \mathrm{ONO}+\mathrm{M}(\mathrm{Y} \equiv \mathrm{Br}, \mathrm{OH}, \mathrm{Cl})$ & $\begin{array}{l}k_{0}=4.3 \times 10^{-30}(T / 298)^{-5.9} \\
k_{\infty}=1.2 \times 10^{-10}(T / 298)^{-1.9}\end{array}$ & $53,46^{d}$ \\
\hline $\mathrm{YHg}^{\mathrm{I}}+Z+\mathrm{M} \rightarrow \mathrm{YHg}^{\mathrm{II}} Z+\mathrm{M}\left(Y \equiv \mathrm{Br}, \mathrm{OH}, \mathrm{Cl} ; Z \equiv \mathrm{HO}_{2}, \mathrm{BrO}, \mathrm{ClO}\right)$ & $\begin{array}{l}k_{0}=4.3 \times 10^{-30}(T / 298)^{-5.9} \\
k_{\infty}=6.9 \times 10^{-11}(T / 298)^{-2.4}\end{array}$ & $53,46^{d, f}$ \\
\hline $\mathrm{YHg}^{\mathrm{I}}+Z(+\mathrm{M}) \rightarrow Y \mathrm{Hg}^{\mathrm{II}} Z(+\mathrm{M})\left(Y \equiv \mathrm{Br}, \mathrm{OH}, \mathrm{Cl}_{;} Z \equiv \mathrm{Br}, \mathrm{Cl}, \mathrm{OH}\right)$ & $3.0 \times 10^{-11}$ & $53^{d, g}$ \\
\hline $\mathrm{YHg}^{\mathrm{I}}+\mathrm{NO}_{2} \rightarrow \mathrm{Hg}^{0}+\mathrm{YNO}_{2}(Y \equiv \mathrm{Br}, \mathrm{Cl})$ & $3.0 \times 10^{-12}$ & $53^{d}$ \\
\hline $\mathrm{BrHg}^{\mathrm{I}}+\mathrm{Br} \rightarrow \mathrm{Hg}^{0}+\mathrm{Br}_{2}$ & $3.9 \times 10^{-11}$ & 43 \\
\hline $\mathrm{ClHg}^{\mathrm{I}}+\mathrm{Cl} \rightarrow \mathrm{Hg}^{0}+\mathrm{Cl}_{2}$ & $1.2 \times 10^{-11} \exp (-5942 / T)$ & 111 \\
\hline
\end{tabular}

${ }^{a_{T}}$ The rate coefficients have units of $\mathrm{cm}^{3} \mathrm{molec}^{-1} \mathrm{~s}^{-1}$ for bimolecular reactions and $\mathrm{cm}^{6} \mathrm{molec}^{-2} \mathrm{~s}^{-1}$ for $k_{0}$ of three-body reactions. The second-order rate coefficient for three-body reactions is calculated as $k([M])=\left(\frac{k_{0}[M]}{1+k_{0}[M] / k_{\infty}}\right) 0.6^{p}$, where $[M]$ is the number density of air molecules and $p=$ $\left.\left(1+\left(\log _{10}\left(k_{0}[M]\right) / k_{\infty}\right)\right)^{2}\right)^{-1}$. Only $k_{0}$ is given when the low-pressure limit dominates in the atmosphere and the second-order rate coefficient is then calculated as $k_{0}[M]$. For thermal dissociation reactions, the rate coefficient is calculated as $k=k_{0} / K_{\text {eq }}$ where $k_{0}$ is the rate coefficient of the forward (association) reaction given in the preceding entry and $K_{\mathrm{eq}}$ is the equilibrium constant in units of $\mathrm{cm}^{3} \mathrm{molec}^{-1}$. T is absolute temperature in $\mathrm{K}$. ${ }^{b}$ The rate coefficient was calculated by Dibble et al. ${ }^{6}$ from the experimental results of Pal and Ariya. ${ }^{55}{ }^{c}$ Saiz-Lopez et al. ${ }^{5}$ estimated an upper limit for the rate coefficient of $1.0 \times 10^{-10} \mathrm{~cm}^{3}$ molec $^{-1} \mathrm{~s}^{-1}$, assuming no steric effects. ${ }^{d}$ We assume that the $\mathrm{BrHg}^{\mathrm{I}}+Z$ rate coefficients hold for $\mathrm{HOHg}+Z$ and $\mathrm{ClHg}^{\mathrm{I}}+Z$ because of the similar bond energies and reactions pathways for the three species, ${ }^{6,19}$ and that the $\mathrm{BrHg}{ }^{\mathrm{II}} \mathrm{O}+Z \mathrm{Zate}$ coefficients hold for $\mathrm{HOHg}{ }^{\mathrm{II}} \mathrm{O}+\mathrm{Z}$ and $\mathrm{ClHg}{ }^{\mathrm{II}} \mathrm{O}+Z$. ${ }^{e}$ Khiri et al. ${ }^{4}$ calculated the range for the rate coefficient of the $\mathrm{BrHg}^{\mathrm{II}} \mathrm{O}+\mathrm{CO} \rightarrow \mathrm{BrHg}^{\mathrm{I}}+\mathrm{CO}_{2}$ reaction at two temperatures: $(9.4-52) \times 10^{-12} \mathrm{~cm}^{3} \mathrm{molec}^{-1} \mathrm{~s}^{-1}$ at $298 \mathrm{~K}$ and $(3.8-29) \times 10^{-12} \mathrm{~cm}^{3} \mathrm{molec}^{-1} \mathrm{~s}^{-1}$ at $220 \mathrm{~K}$. We use the mean values at each temperature to determine the temperature-dependent rate coefficient. ${ }^{\circ} \mathrm{We}$ assume that the experimentally determined value of $k_{0}$ for the $\mathrm{BrHg}^{\mathrm{I}}+\mathrm{NO}_{2}$ reaction ${ }^{53}$ holds for this set of reactions too. ${ }^{g}$ These reactions take place at the high-pressure limit in the atmosphere and the rate coefficient is given for the effective bimolecular reactions.

atmospheric $\mathrm{Hg}^{0}$ oxidation pathways including in aerosols and clouds are thought to be negligible because of either slow rates or low oxidant concentrations. ${ }^{33}$

Partitioning of gas-phase $\mathrm{Hg}^{\mathrm{II}}$ species into aerosols and cloud droplets adds further complexity to the problem. Atmospheric observations indicate that this partitioning is governed by thermodynamic equilibrium. ${ }^{35}$ Once in the condensed phase, $\mathrm{Hg}^{\mathrm{II}}$ may respeciate as different inorganic and organic complexes that then partition back to the gas phase. ${ }^{36} \mathrm{Hg}^{\mathrm{II}} \mathrm{Cl}_{2}$ produced in this manner is stable against photolysis, ${ }^{1}$ and could thus dominate the $\mathrm{Hg}^{\mathrm{II}}$ pool. $\mathrm{Hg}^{\mathrm{II}}-$ organic complexes photoreduce to $\mathrm{Hg}^{0}$ though not as quickly as some of the inorganic complexes. ${ }^{1,37}$

Although uncertainties in the $\mathrm{Hg}^{0} / \mathrm{Hg}^{\mathrm{I}} / \mathrm{Hg}^{\mathrm{II}}$ atmospheric redox cycling remain large, we show here that the most recent laboratory and computational data can be accommodated in a chemical mechanism that reproduces the main features of atmospheric observations and thus provides a basis for $\mathrm{Hg}$ modeling. We implement this mechanism in the GEOS-Chem global model, which has been used extensively for the study of atmospheric $\mathrm{Hg}$ and its cycling with ocean and land reservoirs. ${ }^{21,33,38-42}$ Our work represents a major revision to the previous GEOS-Chem mechanism described by Horowitz et al. ${ }^{33}$

\section{MATERIALS AND METHODS}

Chemical Mechanism. Table $1 \mathrm{a}-\mathrm{c}$ lists the chemical mechanism and Figure 1 shows the main reaction pathways. $\mathrm{Hg}^{0}$ oxidation is initiated by the radicals $\mathrm{Y} \equiv \mathrm{Br}, \mathrm{Cl}$, and $\mathrm{OH}$, forming weakly bound intermediates, $Y \mathrm{Hg}^{\mathrm{I}}$, that further add another radical, $Z$, to form $Y \mathrm{Hg}^{\mathrm{II}} Z$ :

$$
\begin{aligned}
& \mathrm{Hg}^{0}+Y+\mathrm{M} \leftrightarrow Y \mathrm{Hg}^{\mathrm{I}}+\mathrm{M} \\
& Y \mathrm{Hg}^{\mathrm{I}}+Z+\mathrm{M} \rightarrow Y \mathrm{Hg}^{\mathrm{II}} Z+\mathrm{M}
\end{aligned}
$$

The reaction of $\mathrm{Hg}^{0}$ with $\mathrm{Br}$ is exothermic and barrierless, ${ }^{16,17,43}$ and its kinetics have been experimentally measured. ${ }^{44,45} \mathrm{BrHg}^{\mathrm{I}}$ has a low bond energy and dissociates thermally within minutes, ${ }^{18,19}$ but its association reactions with $\mathrm{Z} \equiv \mathrm{OH}, \mathrm{Br}, \mathrm{NO}_{2}, \mathrm{HO}_{2}, \mathrm{BrO}, \mathrm{ClO}$ are also barrierless and fast. ${ }^{17,19,46} \mathrm{BrHg}^{\mathrm{II}} \mathrm{ONO}$ and $\mathrm{BrHg}^{\mathrm{II}} \mathrm{OOH}$ are thought to be the major products due to the abundance of $\mathrm{NO}_{2}$ and $\mathrm{HO}_{2} \cdot{ }^{19,46,47}$ $\mathrm{BrHg}^{\mathrm{I}}$ does not abstract hydrogen atoms and is inefficient in adding to $\mathrm{C}=\mathrm{C}$ double bonds. ${ }^{48}$ It undergoes displacement reactions with certain radicals $\left(Z_{1} \equiv \mathrm{NO}_{2}\right.$ and $\left.\mathrm{Br}\right)$ to return $\mathrm{Hg}^{0}: 43,46$

$$
Y \mathrm{Hg}^{\mathrm{I}}+Z_{1} \rightarrow \mathrm{Hg}^{0}+Y Z_{1}
$$

This chemistry has been included previously in the GEOSChem mechanism ${ }^{33,49}$ and other models. ${ }^{50-52}$ Here we update the rate coefficient for reactions $\mathrm{R} 2$ and $\mathrm{R} 3$ based on recent laboratory measurement of the $\mathrm{BrHg}^{\mathrm{I}}+\mathrm{NO}_{2}$ reaction. ${ }^{53}$

The $\mathrm{OH}$-initiated oxidation of $\mathrm{Hg}^{0}$ to $\mathrm{Hg}^{\mathrm{II}}$ also proceeds by the $\mathrm{R} 1-\mathrm{R} 2$ two-step mechanism, and $\mathrm{HOHg}^{\mathrm{I}}$ is analogous to $\mathrm{BrHg}^{\mathrm{I}}$ in forming thermally stable $\mathrm{HOHg}^{\mathrm{II}} \mathrm{Z}\left(\mathrm{Z} \equiv \mathrm{NO}_{2}, \mathrm{HO}_{2}\right.$, etc.) species. ${ }^{6,17,25} \mathrm{The} \mathrm{Hg}^{0}+\mathrm{OH}+\mathrm{M} \rightarrow \mathrm{HOHg}^{\mathrm{I}}+\mathrm{M}$ reaction is exothermic and fast, ${ }^{54-56}$ but theoretical calculations by Goodsite et al. ${ }^{17}$ found $\mathrm{HOHg}^{\mathrm{I}}$ to be so weakly bound that it would thermally decompose rather than form 
$\mathrm{Hg}^{\mathrm{II}}$. As a result, this pathway was discounted in past GEOSChem mechanisms. ${ }^{33,57}$ However, Dibble et al. ${ }^{6}$ found a much higher bond energy for $\mathrm{HOHg}^{\mathrm{I}}$ and so we reconsider this pathway here.

Oxidation of $\mathrm{Hg}^{0}$ by $\mathrm{Cl}$ atoms is fast ${ }^{32,44}$ and $\mathrm{ClHg}^{\mathrm{I}}$ is thermally stable, but tropospheric $\mathrm{Cl}$ concentrations are low. We include it using GEOS-Chem $\mathrm{Cl}$ concentrations from Wang et al. ${ }^{58}$ but find that it accounts for less than $1 \%$ of global tropospheric $\mathrm{Hg}^{\mathrm{O}}$ conversion to $\mathrm{Hg}^{\mathrm{II}}$. Horowitz et al. ${ }^{33}$ included the aqueous-phase oxidation of $\mathrm{Hg}^{0}$ by $\mathrm{HOCl}, \mathrm{OH}$, and ozone in cloud droplets but found them to be negligible due to the low solubility of $\mathrm{Hg}^{0}$ and we do not include them in our mechanism.

Standard chemical mechanisms for atmospheric $\mathrm{Hg}$, including Horowitz et al., ${ }^{33}$ do not include gas-phase photoreduction of $\mathrm{Hg}^{\mathrm{II}}$. However, theoretical calculations indicate that $\mathrm{BrHg}^{\mathrm{II}} \mathrm{Z}\left(\mathrm{Z} \equiv \mathrm{NO}_{2}, \mathrm{HO}_{2}, \mathrm{OH}, \mathrm{BrO}, \mathrm{ClO}\right)$ species rapidly photolyze. ${ }^{1,3}$ The major $\mathrm{Hg}^{\mathrm{II}}$ species, $\mathrm{BrHg}{ }^{\mathrm{II}} \mathrm{ONO}$ and $\mathrm{BrHg}^{\mathrm{II}} \mathrm{OOH}$, photolyze on a time scale of minutes. ${ }^{1,2} \mathrm{YHg}^{\mathrm{I}}(\mathrm{Y} \equiv \mathrm{Br}, \mathrm{Cl}, \mathrm{OH})$ species also photodissociate rapidly to $\mathrm{Hg}^{0} .59$

Saiz-Lopez et al. ${ }^{5}$ found that including $\mathrm{Hg}^{\mathrm{I}}$ and $\mathrm{Hg}^{\mathrm{II}}$ photolysis in their global model greatly lowered the net conversion rate of $\mathrm{Hg}^{0}$ to $\mathrm{Hg}^{\mathrm{II}}$ and led to large overestimate of atmospheric $\mathrm{Hg}^{0}$ concentrations. Their results implied a missing $\mathrm{Hg}$ oxidation pathway in current mechanisms, and they suggested the oxidation of $\mathrm{BrHg}^{\mathrm{I}}$ by ozone:

$$
\mathrm{BrHg}^{\mathrm{I}}+\mathrm{O}_{3} \rightarrow \mathrm{BrHg}^{\mathrm{II}} \mathrm{O}+\mathrm{O}_{2}
$$

Reaction R4 is strongly exothermic. ${ }^{60}$ Theoretical calculations by Saiz-Lopez et al. ${ }^{\text {s }}$ suggest that it is likely barrierless and produces the $\mathrm{BrHg}^{\mathrm{II}} \mathrm{O}$ radical. Using methods similar to theirs (density functional theory), as well as more advanced CASPT2 calculations, we also find no barrier (Supporting Information (SI) Figure S1). Preliminary experimental data indicate a high rate constant consistent with the absence of barrier (SI Figure S2). We find that the analogous reaction of $\mathrm{HOHg}^{\mathrm{I}}$ with ozone also lacks a barrier and has similar exothermicity to reaction R4 (SI Figure S3), reflecting the similarity between $\mathrm{BrHg}^{\mathrm{I}}$ and HOHg. ${ }^{6}$ Saiz-Lopez et al. ${ }^{5}$ estimated an upper limit of $1 \times$ $10^{-10} \mathrm{~cm}^{3} \mathrm{molec}^{-1} \mathrm{~s}^{-1}$ for the rate coefficient of reaction R4, assuming no steric effects. Here we estimate a rate coefficient of $3 \times 10^{-11} \mathrm{~cm}^{3} \mathrm{molec}^{-1} \mathrm{~s}^{-1}$ for the reaction of $Y \mathrm{Hg}^{\mathrm{I}}$ with ozone $(Y \equiv \mathrm{Br}, \mathrm{OH}, \mathrm{Cl})$.

The $\mathrm{BrHg}^{\mathrm{II}} \mathrm{O}$ radical is also formed from the photolysis of certain $\mathrm{BrHg}^{\mathrm{II}} \mathrm{Z}$ species (Table $1 \mathrm{~b}$ ). Its reactivity mimics that of $\mathrm{OH}$, and it forms stable $\mathrm{Hg}^{\mathrm{II}}$ species by abstracting $\mathrm{H}$ atoms from methane and other volatile organic compounds, or by associating with $\mathrm{NO}$ and $\mathrm{NO}_{2}$, with the methane reaction dominating. ${ }^{2,20}$ Khiri et $\mathrm{al}^{4}$ found that $\mathrm{BrHg}^{\mathrm{II}} \mathrm{O}$ can also be reduced to $\mathrm{BrHg}^{\mathrm{I}}$ by $\mathrm{CO}$. $\mathrm{BrHg}^{\mathrm{II}} \mathrm{O}$ photolysis in the troposphere is relatively slow. ${ }^{3}$ Thus, we include the following reactions in our mechanism:

$$
\begin{aligned}
& Y \mathrm{Hg}^{\mathrm{I}}+\mathrm{O}_{3} \rightarrow Y \mathrm{Hg}^{\mathrm{II}} \mathrm{O}+\mathrm{O}_{2} \\
& Y \mathrm{Hg}^{\mathrm{II}} \mathrm{O}+\mathrm{CH}_{4} \rightarrow Y \mathrm{Hg}^{\mathrm{II}} \mathrm{OH}+\mathrm{CH}_{3} \\
& Y \mathrm{Hg}^{\mathrm{II}} \mathrm{O}+\mathrm{CO} \rightarrow Y \mathrm{Hg}^{\mathrm{I}}+\mathrm{CO}_{2}
\end{aligned}
$$

$\mathrm{Hg}^{\mathrm{II}}$ species are absorbed by aqueous aerosol particles and cloud droplets and dissociate to $\mathrm{Hg}^{2+}$ ions, which repartition to

\begin{tabular}{|c|c|c|c|}
\hline reaction & $\phi$ & $J\left(\mathrm{~s}^{-1}\right)^{b}$ & references \\
\hline $\mathrm{BrHg}^{\mathrm{I}}+h \nu \rightarrow \mathrm{Hg}^{0}+\mathrm{Br}$ & 1.0 & $4.3 \times 10^{-2}$ & 59 \\
\hline $\mathrm{HOHg}^{\mathrm{I}}+h \nu \rightarrow \mathrm{Hg}^{0}+\mathrm{OH}$ & 1.0 & $1.6 \times 10^{-2}$ & 59 \\
\hline $\begin{array}{l}\mathrm{YHg}^{\mathrm{II}} \mathrm{OH}+h \nu \rightarrow \mathrm{Hg}^{0}+Y+\mathrm{OH}(Y \equiv \\
\mathrm{Br}, \mathrm{Cl})\end{array}$ & 0.49 & $1.3 \times 10^{-5}$ & $1,3,5^{c}$ \\
\hline$\rightarrow \mathrm{HOHg}^{\mathrm{I}}+Y$ & 0.35 & & \\
\hline$\rightarrow \mathrm{YHg}^{\mathrm{I}}+\mathrm{OH}$ & 0.15 & & \\
\hline$\rightarrow \mathrm{YHg}^{\mathrm{II}} \mathrm{O}+\mathrm{H}$ & 0.01 & & \\
\hline $\begin{array}{l}\mathrm{YHg}^{\mathrm{II}} \mathrm{ONO}+h \nu \rightarrow \mathrm{YHg}^{\mathrm{II}} \mathrm{O}+\mathrm{NO}(Y \\
\equiv \mathrm{Br}, \mathrm{Cl}, \mathrm{OH})\end{array}$ & 0.90 & $1.1 \times 10^{-3}$ & $1,3,5,2^{c, d}$ \\
\hline$\rightarrow \mathrm{YHg}^{\mathrm{I}}+\mathrm{NO}_{2}$ & 0.10 & & \\
\hline $\begin{array}{l}\mathrm{YHg}^{\mathrm{II}} \mathrm{OOH}+h \nu \rightarrow \mathrm{Hg}^{0}+Y+\mathrm{HO}_{2}(Y \\
\equiv \mathrm{Br}, \mathrm{Cl}, \mathrm{OH})\end{array}$ & 0.66 & $1.5 \times 10^{-2}$ & $1,3,5^{c, d}$ \\
\hline$\rightarrow \mathrm{YHg}^{\mathrm{II}} \mathrm{O}+\mathrm{OH}$ & 0.31 & & \\
\hline$\rightarrow \mathrm{YHg}^{\mathrm{I}}+\mathrm{HO}_{2}$ & 0.03 & & \\
\hline $\begin{array}{l}\mathrm{YHg}^{\mathrm{II}} \mathrm{OBr}+h \nu \rightarrow \mathrm{YHg}^{\mathrm{I}}+\mathrm{BrO}(Y \equiv \\
\quad \mathrm{Br}, \mathrm{OH}, \mathrm{Cl})\end{array}$ & $1.0^{e}$ & $2.4 \times 10^{-2}$ & $1^{d}$ \\
\hline $\begin{array}{l}\mathrm{YHg}^{\mathrm{II}} \mathrm{OCl}+h \nu \rightarrow \mathrm{YHg}^{\mathrm{I}}+\mathrm{ClO}(Y \equiv \\
\quad \mathrm{Br}, \mathrm{OH}, \mathrm{Cl})\end{array}$ & $1.0^{e}$ & $1.4 \times 10^{-2}$ & $1^{d}$ \\
\hline $\mathrm{Hg}^{\mathrm{II}} \mathrm{Br}_{2}+h \nu \rightarrow \mathrm{BrHg}^{\mathrm{I}}+\mathrm{Br}$ & 0.60 & $1.2 \times 10^{-6}$ & $1,5^{c}$ \\
\hline$\rightarrow \mathrm{Hg}^{0}+2 \mathrm{Br}$ & 0.40 & & \\
\hline $\mathrm{Hg}^{\mathrm{II}} \mathrm{P}($ org $)+h \nu \rightarrow \mathrm{Hg}^{0}$ & 1.0 & $1.9 \times 10^{-5}$ & this work ${ }^{f}$ \\
\hline
\end{tabular}
form inorganic and organic complexes. ${ }^{36} \mathrm{We}$ refer to total particulate mercury as $\mathrm{Hg}^{\mathrm{II}} \mathrm{P} . \mathrm{Hg}^{\mathrm{II}} \mathrm{Cl}_{2}, \mathrm{Hg}^{\mathrm{II}} \mathrm{Cl}_{3}{ }^{-}$, and $\mathrm{Hg}^{\mathrm{II}} \mathrm{Cl}_{4}{ }^{2-}$
Table 1b. Chemical Mechanism: Photolysis Reactions ${ }^{a}$

${ }^{a}$ Photolysis frequencies are calculated using Fast-JX v7.0a ${ }^{112}$ implemented in GEOS-Chem by Eastham et al. ${ }^{77} \phi$ represents the branching fractions for the dissociation channels. $\mathrm{Hg}^{\mathrm{II}}(\mathrm{OH})_{2}$ and $\mathrm{Hg}^{\mathrm{II}} \mathrm{Cl}_{2}$ are not shown in the table because they do not photolyze at tropospheric wavelengths. ${ }^{1,113}{ }^{b}$ Global annual mean tropospheric photolysis frequencies in GEOS-Chem. ${ }^{c}$ Photolysis cross sections are from Saiz-Lopez et al. ${ }^{5}$ and branching fractions from FrancésMonerris et al. ${ }^{3}$ and Saiz-Lopez et al. ${ }^{5}{ }^{d}$ Photolysis cross sections for $\mathrm{HOHg}^{\mathrm{II}} \mathrm{Z}$ and $\mathrm{ClHg}^{\mathrm{II}} \mathrm{Z}\left(\mathrm{Z} \equiv \mathrm{NO}_{2}, \mathrm{HO}_{2}, \mathrm{BrO}\right.$, and $\left.\mathrm{ClO}\right)$ are assumed to be same as for $\mathrm{BrHg}^{\mathrm{II} Z} Z$. ${ }^{e}$ Sole photolysis pathway considered in Saiz-Lopez et al. ${ }^{1}{ }^{f}$ The photolysis frequency of this reaction is parametrized as $J_{\mathrm{HgIIP}(\mathrm{org})}=\beta J_{\mathrm{NO} 2}$, where $J_{\mathrm{NO} 2}$ is the local photolysis frequency of $\mathrm{NO}_{2}$ and the scaling factor $\beta$ is adjusted to match the global mean $\mathrm{Hg}^{0}$ surface observations. For our standard simulation we use $\beta=4 \times 10^{-3}$, and for the sensitivity simulation with the Schmidt et al. ${ }^{80} \mathrm{Br}$ fields we use $\beta=4 \times 10^{-2}$.

are expected to be the dominant inorganic $\mathrm{Hg}^{\mathrm{II}}$ species in the troposphere because of the abundance of $\mathrm{Cl}^{-}$. ${ }^{1,62} \mathrm{Hg}^{\mathrm{II}}-$ organic complexes may also form, involving in particular the carboxyl and thiol functional groups. ${ }^{63,64}$ In stratospheric sulfuric acid aerosols, $\mathrm{Hg}^{\mathrm{II}}$ likely remains in free ionic form because of the low stability of the $\mathrm{Hg}^{\mathrm{II}}$-sulfate complex. While the thermodynamics of the $\mathrm{Hg}^{\mathrm{II}}$-chloride complexes are known, ${ }^{36}$ there is little information on the $\mathrm{Hg}^{\mathrm{II}}$-organic complexes in atmospheric waters. We choose to represent the inorganic and organic complexes by two species- $\mathrm{Hg}^{\mathrm{II}} \mathrm{P}$ (inorg) and $\mathrm{Hg}^{\mathrm{II}} \mathrm{P}$ (org) - and partition the dissolved $\mathrm{Hg}^{\mathrm{II}}$ into these two complexes based on the local relative mass fractions of inorganic and organic aerosol material (Table 1c). Volatilization of $\mathrm{Hg}^{\mathrm{II}}$ from aerosols is as a parametrized species, $\mathrm{Hg}^{\mathrm{II}} \mathrm{X}$, that is stable against photolysis. We assume for modeling purposes that $\mathrm{Hg}^{\mathrm{II} X}$ is $\mathrm{Hg}^{\mathrm{II}} \mathrm{Cl}_{2}$, which does not photolyze at tropospheric wavelengths, ${ }^{5}$ but it could also include other stable $\mathrm{Hg}^{\mathrm{II}}$ species, hence the parametrized representation.

Photoreduction of $\mathrm{Hg}^{\mathrm{II}}$ to $\mathrm{Hg}^{0}$ has long been known to occur in atmospheric waters. ${ }^{65}$ It was initially thought to involve sulfite ions or $\mathrm{HO}_{2}$ as reductants, ${ }^{66,67}$ but it most likely takes place through the direct light absorption by $\mathrm{Hg}^{\text {II }}$-organic complexes followed by transfer of two electrons from the ligand to $\mathrm{Hg}^{68,69} \mathrm{Hg}^{\mathrm{II}}$ photoreduction is known to involve 
Table 1c. Chemical Mechanism: Multiphase Processes

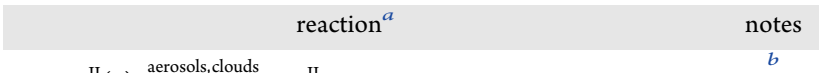

$$
\begin{aligned}
& \mathrm{Hg}^{\mathrm{II}}(\mathrm{g}) \stackrel{\text { aerosols,clouds }}{\longrightarrow} \mathrm{Hg}^{\mathrm{II}} \mathrm{P} \\
& \mathrm{Hg}^{\mathrm{II}} \mathrm{P} \stackrel{\text { aerosols }}{\longrightarrow} \mathrm{Hg}^{\mathrm{II}} \mathrm{X}(\mathrm{g}) \\
& \mathrm{Hg}^{\mathrm{II}} \mathrm{P} \equiv\left\{\begin{array}{cc}
\mathrm{Hg}^{\mathrm{II}} \mathrm{P}(\text { org })+\mathrm{Hg}^{\mathrm{II}} \mathrm{P}(\text { inorg }) & \text { (troposphere) } \\
\mathrm{Hg}^{2+} & \text { (stratosphere) }
\end{array}\right.
\end{aligned}
$$

${ }^{a} \mathrm{Hg}^{\mathrm{II}}(\mathrm{g})$ and $\mathrm{Hg}^{\mathrm{II}} \mathrm{P}$ represent all gas- and particle-phase $\mathrm{Hg}^{\mathrm{II}}$ species; $\mathrm{Hg}^{\mathrm{II}} \mathrm{X}(\mathrm{g})$ represents the unspeciated $\mathrm{Hg}^{\mathrm{II}}$ gas volatilizing from $\mathrm{Hg}^{\mathrm{II}} \mathrm{P}$ and treated as $\mathrm{Hg}^{\mathrm{II}} \mathrm{Cl}_{2} \cdot{ }^{b} \mathrm{Hg}^{\mathrm{II}}(\mathrm{g})$ uptake rate is given by eq 1 . For clouds, the uptake rate accounts for entrainment limitation in partly cloudy grid cells. ${ }^{87}$ Colatilization is considered only for tropospheric aerosols, not for cloud droplets (because of their large volume) and stratospheric aerosols (because of their high acidity and cold temperature). The volatilization rate is given by eq 2 with equilibrium constant between $\mathrm{Hg}^{\mathrm{II}}(\mathrm{g})$ and $\mathrm{Hg}^{\mathrm{II}} \mathrm{P}$ from Amos et $\mathrm{al}^{35}{ }^{d} \mathrm{Hg}^{\mathrm{II}} \mathrm{P}$ in the tropospheric aerosol speciates as $\mathrm{Hg}^{\mathrm{II}} \mathrm{P}$ (org) and $\mathrm{Hg}^{\mathrm{II}} \mathrm{P}$ (inorg) representing $\mathrm{Hg}^{\mathrm{II}}$-organic and $\mathrm{Hg}^{\mathrm{II}}$-inorganic complexes. Their concentrations are calculated as $\left[\mathrm{Hg}^{\mathrm{II}} \mathrm{P}(\right.$ org $\left.)\right]=f_{\mathrm{OA}}\left[\mathrm{Hg}^{\mathrm{II}} \mathrm{P}\right]$ and $\left[\mathrm{Hg}^{\mathrm{II}} \mathrm{P}(\right.$ inorg $\left.)\right]=\left(1-f_{\mathrm{OA}}\right)\left[\mathrm{Hg}^{\mathrm{II}} \mathrm{P}\right]$, where $f_{\mathrm{OA}}$ is the local mass fraction of organic aerosols in fine particles computed as $f_{\mathrm{OA}}=\frac{m_{\mathrm{OA}}}{m_{\mathrm{OA}}+m_{\mathrm{IA}}}$, with $m_{\mathrm{OA}}$ and $m_{\mathrm{IA}}$ representing the respective mass concentrations of organic and inorganic aerosol components.

$\mathrm{Hg}^{\mathrm{II}}$-organic complexes in aquatic systems. ${ }^{70-72}$ Aqueous $\mathrm{Hg}^{\mathrm{II}}$ photoreduction frequencies of $0.02-0.2 \mathrm{~h}^{-1}$ have been measured in summertime rainwater samples, ${ }^{1}$ consistent with photoreduction frequencies of $\mathrm{Hg}^{\mathrm{II}}$-fulvic acid complexes, ${ }^{37}$ but lower than $0.2-3 \mathrm{~h}^{-1}$ observed in fresh and marine waters. $^{73}$ In our mechanism, we assume that the photoreduction frequency of $\mathrm{Hg}^{\mathrm{II}} \mathrm{P}$ (org) scales as the local $\mathrm{NO}_{2}$ photolysis frequency $\left(J_{\mathrm{NO} 2}\right)$ and adjust the scaling factor $(\beta$ in Table $1 \mathrm{~b}$ ) to fit observed atmospheric $\mathrm{Hg}^{0}$ concentrations. We obtain a scaling factor $\beta=4 \times 10^{-3}$, corresponding to a tropospheric mean $\mathrm{Hg}^{\mathrm{II}} \mathrm{P}$ (org) photoreduction frequency of $0.13 \mathrm{~h}^{-1}$ in clear sky at noon in summer at $45^{\circ} \mathrm{N}$.

GEOS-Chem Model. We implement the chemical mechanism of Table 1 in the global 3-D GEOS-Chem model (www.geos-chem.org; version 12.9.0). The current standard version of the model for $\mathrm{Hg}$ is described by Horowitz et al. ${ }^{33}$ and includes dynamic coupling between the atmosphere and surface reservoirs. Here we focus on the atmospheric reservoir and therefore use gridded land and ocean surface $\mathrm{Hg}$ concentrations from Horowitz et al..$^{33}$ as boundary conditions. Other $\mathrm{Hg}$ emissions (Figure 1) are also from Horowitz et al. ${ }^{33}$ except that anthropogenic $\mathrm{Hg}$ emissions are from Streets et al. $^{74}$ Total $\mathrm{Hg}$ emission in the model is $8.7 \mathrm{Gg} \mathrm{a}^{-1}$, of which 0.8 $\mathrm{Gg} \mathrm{a}^{-1}$ is as $\mathrm{Hg}^{\mathrm{II}}$ (from combustion) and emitted as $\mathrm{Hg}^{\mathrm{II}} \mathrm{X}$ (Figure 1).

We drive our simulation with assimilated meteorological fields from the NASA Modern-Era Retrospective Analysis for Research and Applications, version 2 (MERRA-2) system. $^{75}$ We conduct a three-year global simulation (2013-2015) at $4^{\circ}$ latitude by $5^{\circ}$ longitude resolution following a spin-up period of 15 years to equilibrate the stratosphere. The chemical mechanism is implemented using the Kinetic PreProcessor $(\mathrm{KPP})^{76}$ customized for GEOS-Chem, and the chemical evolution is computed every hour on the model grid.

GEOS-Chem in its "full-chemistry" implementation includes detailed oxidant-aerosol chemistry in the troposphere and stratosphere. $^{34,77-79}$ For computational efficiency, the $\mathrm{Hg}$ simulation in GEOS-Chem uses monthly oxidant and aerosol concentrations archived from that full-chemistry simulation. Horowitz et al. ${ }^{33}$ used $\mathrm{Br}$ concentration fields from Schmidt et al. ${ }^{80}$ but these are now thought to be too high ${ }^{81}$ and do not include the known source of bromine radicals from debromination of sea salt aerosols (SSA). ${ }^{82}$ Here we use updated oxidant and aerosol fields from GEOS-Chem version 12.9, with major update of bromine chemistry to include mechanistic SSA debromination and less efficient heterogeneous recycling of bromine radicals. ${ }^{58}$ The tropospheric mean $\mathrm{Br}$ and $\mathrm{BrO}$ concentrations are 0.03 and 0.19 pptv, respectively, compared to 0.08 and $0.48 \mathrm{pptv}$ in Schmidt et al., ${ }^{80}$ but concentrations are higher in the marine boundary layer (MBL) because of SSA debromination (SI Figure S4). Tropospheric bromine chemistry remains very uncertain, ${ }^{58}$ therefore we also conduct a sensitivity simulation using the Schmidt et al. ${ }^{80} \mathrm{Br}$ and $\mathrm{BrO}$ fields. We apply a diurnal scaling to the monthly mean oxidant concentrations using the $Y-Y \mathrm{O}-$ $\mathrm{O}_{3}-\mathrm{NO}(\mathrm{Y} \equiv \mathrm{Br}, \mathrm{Cl})$ photochemical equilibrium for the daytime concentrations of $\mathrm{Br}, \mathrm{BrO}, \mathrm{Cl}, \mathrm{ClO}$ following Holmes et $\mathrm{al}{ }^{57}$ a cosine function of the solar zenith angle for daytime $\mathrm{OH}$ and $\mathrm{HO}_{2}$; and $\mathrm{NO}-\mathrm{NO}_{2}-\mathrm{O}_{3}$ photochemical equilibrium for $\mathrm{NO}_{2} . \mathrm{Br}$ and $\mathrm{BrO}$ concentrations in the polar springtime boundary layer are calculated following Fisher et al. ${ }^{83}$

We treat the transfer of $\mathrm{Hg}^{\mathrm{II}}$ between the gas phase and the aerosol/cloud phase as a kinetic process. Individual gas-phase species $\mathrm{Hg}_{i}^{\mathrm{II}}$ are taken up by aerosols and cloud droplets where they are respeciated to the $\mathrm{Hg}^{\mathrm{II}} \mathrm{P}$ (org) and $\mathrm{Hg}^{\mathrm{II}} \mathrm{P}$ (inorg) forms, and then volatilized (for aerosols) as the $\mathrm{Hg}^{\mathrm{II}} \mathrm{X}$ form. The rate of uptake and volatilization of $\mathrm{Hg}^{\mathrm{II}}$ gaseous species is calculated as ${ }^{84,85}$

$$
\begin{aligned}
& -\frac{\mathrm{d}\left[\mathrm{Hg}_{i}^{\mathrm{II}}(\mathrm{g})\right]}{\mathrm{d} t}=k_{\mathrm{mt}}\left[\mathrm{Hg}_{i}^{\mathrm{II}}(\mathrm{g})\right] \\
& \frac{\mathrm{d}\left[\mathrm{Hg}^{\mathrm{II}} \mathrm{X}(\mathrm{g})\right]}{\mathrm{d} t}=k_{\mathrm{mt}}\left[\mathrm{Hg}^{\mathrm{II}}(\mathrm{g})\right]_{\mathrm{eq}}
\end{aligned}
$$

where $\left[\mathrm{Hg}_{i}^{\mathrm{II}}(\mathrm{g})\right]$ is the number density of $\mathrm{Hg}_{i}^{\mathrm{II}}(\mathrm{g}), k_{\mathrm{mt}}$ is the mass transfer rate coefficient $\left(\mathrm{s}^{-1}\right)$, and $\left[\mathrm{Hg}^{\mathrm{II}}(\mathrm{g})\right]_{\mathrm{eq}}$ is calculated on the basis of equilibrium between total $\mathrm{Hg}^{\mathrm{II}}$ in the gas and aerosol phases using the empirical equilibrium constant of Amos et al. ${ }^{35}$ as a function of local temperature and mass concentration of fine particulate matter. For cloud droplets, we assume no mass transfer back to the gas phase because of the high solubility of $\mathrm{Hg}^{\mathrm{II}}$. Uptake on coarse-mode SSA follows Holmes et al. ${ }^{57} k_{\mathrm{mt}}$ for aerosols is calculated as

$$
k_{\mathrm{mt}}=\sum_{j} S_{j}\left(\frac{r_{j}}{D_{\mathrm{g}}}+\frac{4}{\nu \alpha}\right)^{-1}
$$

where $r_{j}$ and $S_{j}$ are the effective mean area-weighted radius and surface area per unit volume of air of each aerosol component (j), $D_{\mathrm{g}}$ is the gas-phase molecular diffusion coefficient of $\mathrm{Hg}^{\mathrm{II}}$ gas, $\nu$ is the mean molecular speed of $\mathrm{Hg}^{\mathrm{II}}$ gas, and $\alpha$ is the mass accommodation coefficient. We take $\alpha=0.1$ for all $\mathrm{Hg}^{\mathrm{II}}$ gas species in the model since $\alpha$ for other highly soluble species generally has values of $0.1-0.3 .^{86} k_{\mathrm{mt}}$ for cloud droplets is calculated similarly but also accounts for entrainment limitation in partly cloudy grid cells. ${ }^{87}$

\section{RESULTS AND DISCUSSION}

Global Atmospheric Hg Budget. Figure 1 shows the global model $\mathrm{Hg}$ budget for the troposphere and the major 
pathways for $\mathrm{Hg}^{0} / \mathrm{Hg}^{\mathrm{I}} / \mathrm{Hg}^{\mathrm{II}}$ redox cycling. The tropospheric mass of $\mathrm{Hg}$ is $4 \mathrm{Gg}\left(3.9 \mathrm{Gg}\right.$ as $\mathrm{Hg}^{0}$ and $0.1 \mathrm{Gg}$ as $\left.\mathrm{Hg}^{\mathrm{II}}\right)$. The stratosphere contains an additional $0.8 \mathrm{Gg}$ (not shown in Figure 1). The tropospheric lifetime of total $\mathrm{Hg}$ $\left(\mathrm{Hg}^{0}+\mathrm{Hg}^{\mathrm{I}}+\mathrm{Hg}^{\mathrm{II}}\right)$ against deposition is 5.5 months. The simulated $\mathrm{Hg}$ mass and lifetime are within observationally constrained values of $\sim 4 \mathrm{Gg}$ for the tropospheric $\mathrm{Hg}$ mass and 4-7 months for the Hg lifetime. ${ }^{5,23,33,57}$ The previous GEOSChem simulation of Horowitz et al. ${ }^{33}$ had a tropospheric mass of $\mathrm{Hg}$ of $3.9 \mathrm{Gg}$ and a lifetime against deposition of 5.2 months, similar to ours, but four times as much $\mathrm{Hg}^{\mathrm{II}}(0.4 \mathrm{Gg})$ because of production at higher altitudes (leading to longer lifetime against deposition) and slower photoreduction.

We find that oxidation of $\mathrm{Hg}^{0}$ to $\mathrm{Hg}^{\mathrm{I}}$ takes place by $\mathrm{Br}$ and $\mathrm{OH}$ at similar rates. Ozone is the primary oxidant of $\mathrm{Hg}^{\mathrm{I}}$ to $\mathrm{Hg}^{\mathrm{II}}$ as it is far more abundant than $\mathrm{NO}_{2}$ and $\mathrm{HO}_{2}$, which were the main $\mathrm{Hg}^{\mathrm{I}}$ oxidants in previous mechanisms. ${ }^{1,5,33}$ Photolysis and thermal decomposition of $\mathrm{BrHg}^{\mathrm{I}}$ are much slower than its reaction with ozone, so the main fate of $\mathrm{BrHg}^{\mathrm{I}}$ is oxidation to $\mathrm{BrHg}^{\mathrm{II}} \mathrm{OH}$, via $\mathrm{BrHg}^{\mathrm{II}} \mathrm{O}$. Although $\mathrm{HOHg}^{\mathrm{I}}$ is less stable than $\mathrm{BrHg}^{\mathrm{I}}$ and a smaller fraction of it is converted to $\mathrm{Hg}^{\mathrm{II}}$, the OHinitiated pathway still accounts for one-third of the global $\mathrm{Hg}^{\mathrm{II}}$ production. In comparison, Dibble et al. ${ }^{6}$ had found the $\mathrm{OH}$ initiated pathway to be important only in the urban boundary layer. Including the $\mathrm{HOHg}^{\mathrm{I}}+\mathrm{O}_{3}$ reaction in our mechanism allows the $\mathrm{OH}$-initiated pathway to contribute to $\mathrm{Hg}^{\mathrm{II}}$ production globally. The chemical lifetime of $\mathrm{Hg}^{0}$ against oxidation to $\mathrm{Hg}^{\mathrm{II}}$ in our model is 4.5 months, compared to 2.7 months in Horowitz et al. ${ }^{33}$ and about 13 months in SaizLopez et al. ${ }^{1}$ Using higher free tropospheric Br concentrations from Schmidt et al. ${ }^{80}$ lowers the tropospheric $\mathrm{Hg}$ mass by

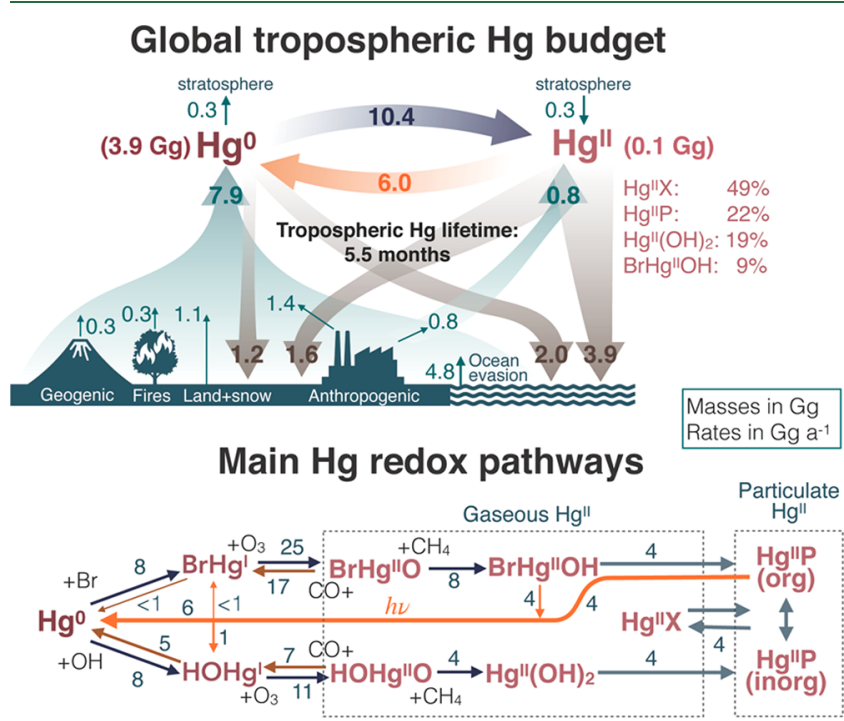

Figure 1. Global tropospheric $\mathrm{Hg}$ budget and main $\mathrm{Hg}$ redox pathways in our simulation for 2013-2015. The $\mathrm{Hg}$ masses and rates are global annual means given in units of $\mathrm{Gg}$ and $\mathrm{Gg} \mathrm{a}^{-1}$ respectively. The tropospheric mass of $\mathrm{Hg}^{\mathrm{I}}$ is very small $\left(3 \times 10^{-6} \mathrm{Gg}\right)$ and not shown. The main $\mathrm{Hg}^{\mathrm{II}}$ species in the model and their percent contributions to the total tropospheric $\mathrm{Hg}^{\mathrm{II}}$ mass are listed. $\mathrm{Hg}^{\mathrm{II}} \mathrm{P}$ denotes particulate $\mathrm{Hg}^{\mathrm{II}}$, which includes $\mathrm{Hg}^{\mathrm{II}}$-organic complexes $\left(\mathrm{Hg}^{\mathrm{II}} \mathrm{P}(\mathrm{org})\right)$, and $\mathrm{Hg}^{\mathrm{II}}$-inorganic complexes ( $\mathrm{Hg}^{\mathrm{II}} \mathrm{P}$ (inorg) $) . \mathrm{Hg}^{\mathrm{II} X}$ denotes the gas-phase $\mathrm{Hg}^{\mathrm{II}}$ species that volatilize from $\mathrm{Hg}^{\mathrm{II}} \mathrm{P}$ and is modeled as $\mathrm{Hg}^{\mathrm{II}} \mathrm{Cl}_{2}$. Oxidation of $\mathrm{Hg}^{0}$ by $\mathrm{Cl}$ atoms is not shown because it accounts only for $<1 \%$ of the $\mathrm{Hg}^{0}$ chemical sink in the troposphere.

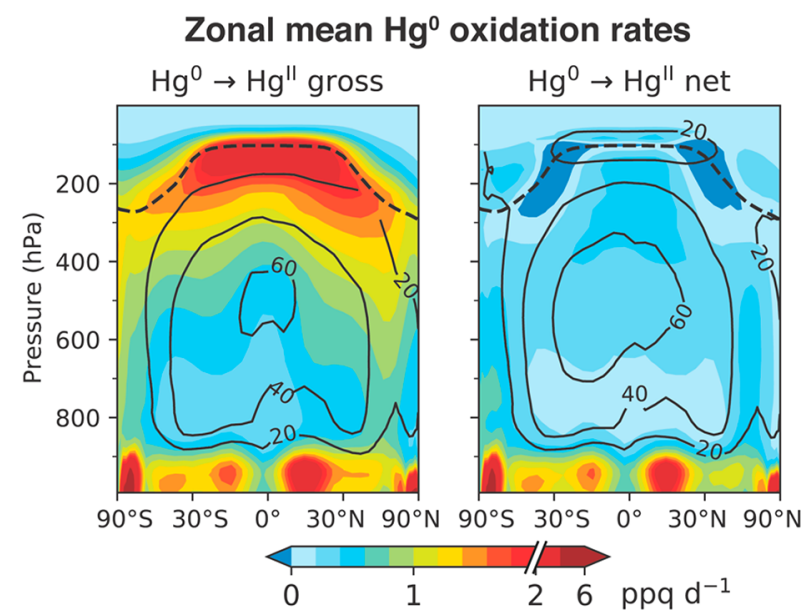

Figure 2. Annual (2013-2015) zonal mean gross and net $\mathrm{Hg}^{0}$ oxidation rates in GEOS-Chem. The contour lines show the percent contribution of the $\mathrm{OH}$-initiated $\mathrm{Hg}^{0}$ oxidation pathway. The dashed line denotes the annual-mean tropopause.

about $10 \%$ due to increased partitioning to $\mathrm{Hg}^{\mathrm{II}}$ and hence faster deposition. $\mathrm{Br}$ then contributes $75 \%$ of $\mathrm{Hg}^{0}$ oxidation (SI Figure S5).

Figure 2 shows the zonal distribution of the $\mathrm{Hg}^{0}$ oxidation rate in our standard simulation. Gross oxidation of $\mathrm{Hg}^{0}$ to $\mathrm{Hg}^{\mathrm{II}}$ is fastest in the $\mathrm{MBL}$ and in the upper troposphere and largely reflects the $\mathrm{Br}$ distribution. $\mathrm{Br}$ concentrations are highest near the tropical tropopause due to fast photolysis of $\mathrm{BrO}$ and low ozone and temperature. ${ }^{88,89}$ The $\mathrm{OH}$-initiated oxidation pathway contributes most to $\mathrm{Hg}^{0}$ oxidation in the tropical free troposphere, as dissociation of $\mathrm{HOHg}^{\mathrm{I}}$ is fast at lower altitudes. ${ }^{6}$ It also dominates in the continental boundary layer, consistent with Gabay et al., ${ }^{90}$ shows the zonal distribution of

$\mathrm{BrHg}^{\mathrm{II}} \mathrm{OH}$ and $\mathrm{Hg}^{\mathrm{II}}(\mathrm{OH})_{2}$ are the main $\mathrm{Hg}^{\mathrm{II}}$ species initially formed from $\mathrm{Hg}^{0}$ oxidation, but the $\mathrm{Hg}^{\mathrm{II}}$ speciation evolves as these species are processed by aerosol and cloud droplets to form $\mathrm{Hg}^{\mathrm{II} P}$ particles and $\mathrm{Hg}^{\mathrm{II} X}$ gas. We find that $\mathrm{Hg}^{\mathrm{II} X}$ (modeled as $\mathrm{Hg}^{\mathrm{II}} \mathrm{Cl}_{2}$ ) is the most abundant form of $\mathrm{Hg}^{\mathrm{II}}$ in the troposphere, comprising $49 \%$ of $\mathrm{Hg}^{\mathrm{II}}$ mass, while $\mathrm{Hg}^{\mathrm{II}} \mathrm{P}$ comprises $22 \%$. The remaining $\mathrm{Hg}^{\mathrm{II}}$ mass is mostly composed of $\mathrm{Hg}^{\mathrm{II}}(\mathrm{OH})_{2}$, which is more abundant than $\mathrm{BrHg}^{\mathrm{II}} \mathrm{OH}$ because it does not photolyze. Most of the reduction of $\mathrm{Hg}^{\mathrm{II}}$ to $\mathrm{Hg}^{0}$ is through the aqueous-phase photolysis of $\mathrm{Hg}^{\mathrm{II}} \mathrm{P}$ (org). The photoreduction rate increases with altitude because of stronger UV radiation and the higher $\mathrm{Hg}^{\mathrm{II}}$ particle fraction at lower temperatures, and it is faster in the northern hemisphere because of the higher fraction of organic aerosol. $\mathrm{Hg}^{\mathrm{II}} \mathrm{P}$ is stable against photoreduction in the stratosphere as it is assumed to be present as free $\mathrm{Hg}^{2+}$.

The net rate of oxidation of $\mathrm{Hg}^{0}$ to $\mathrm{Hg}^{\mathrm{II}}$, accounting for $\mathrm{Hg}^{\mathrm{II}}$ reduction, is $43 \%$ of the gross $\mathrm{Hg}^{0}$ oxidation rate. Net $\mathrm{Hg}^{0}$ oxidation is fastest in the $\mathrm{MBL}$ where $\mathrm{Hg}^{\mathrm{II}}$ photoreduction is slower than deposition. Horowitz et al. ${ }^{33}$ found little net oxidation in the lower troposphere because their simulation had little $\mathrm{Br}$ in the MBL and did not include the $\mathrm{Hg}^{\mathrm{I}}+\mathrm{O}_{3}$ reaction. They had maximum production in the tropical upper troposphere, but here this is largely canceled by photoreduction and we find areas of net reduction as the $\mathrm{Hg}^{\mathrm{II}}$-rich tropical upper tropospheric air is transported poleward by the Hadley circulation. Globally, we find that about half of the net oxidation of $\mathrm{Hg}^{0}$ to $\mathrm{Hg}^{\mathrm{II}}$ takes place through the $\mathrm{OH}$-initiated 
pathway, compared to one-third for gross oxidation, because of the stability of $\mathrm{Hg}^{\mathrm{II}}(\mathrm{OH})_{2}$ against photolysis.

Our results differ substantially from the global model simulation of Saiz-Lopez et al. $^{5}$ They found that including the photolysis of $\mathrm{Hg}^{\mathrm{I}}$ and $\mathrm{Hg}^{\mathrm{II}}$ species increased the $\mathrm{Hg}$ lifetime against deposition to 20 months and the tropospheric $\mathrm{Hg}$ mass to $7.9 \mathrm{Gg}$, twice higher than inferred from atmospheric observations. Including the $\mathrm{BrHg}^{\mathrm{I}}+\mathrm{O}_{3}$ reaction lowered the tropospheric $\mathrm{Hg}$ lifetime to 15 months, which is still too high. The Hg lifetime in their model would have been even longer had they included the recent findings on the reduction of $\mathrm{BrHg}^{\mathrm{II}} \mathrm{O}$ by $\mathrm{CO},{ }^{4}$ and the slower $\mathrm{BrHg}^{\mathrm{I}}+\mathrm{NO}_{2}$ rate coefficient. ${ }^{53}$ The main reasons why we achieve a shorter $\mathrm{Hg}$ lifetime are because we include (1) the $\mathrm{HOHg}+\mathrm{O}_{3}$ reaction, which accounts for half of the net chemical loss of $\mathrm{Hg}^{0}$ in our model; and (2) the respeciation of photolabile $\mathrm{Hg}^{\mathrm{II}}$ species in aerosols and cloud droplets to form more stable species.

Spatial Distribution of $\mathrm{Hg}$ Concentrations and Deposition. Figure 3 shows the modeled zonal distributions of $\mathrm{Hg}^{0}$ and $\mathrm{Hg}^{\mathrm{II}}$ concentrations and compares modeled and observed $\mathrm{Hg}^{0}$ concentrations at the surface. There is little variation in $\mathrm{Hg}^{0}$ concentrations with altitude in the troposphere, both in the model and in aircraft measurements, ${ }^{91-93}$ consistent with the long lifetime of $\mathrm{Hg}^{0}$. Modeled $\mathrm{Hg}^{0}$ concentrations decrease by $\sim 50 \mathrm{ppq}$ within a height of $3 \mathrm{~km}$ above the tropopause, which is somewhat lower than the decrease $(\sim 70 \mathrm{ppq})$ observed from aircraft, ${ }^{93}$ This could reflect excessive mixing across the tropopause in the $4^{\circ} \times 5^{\circ}$ version of the model. ${ }^{94}$ The model captures the observed spatial patterns in surface $\mathrm{Hg}^{0}$ concentrations $(r=0.86)$, which are driven by anthropogenic emissions and the interhemispheric gradient, but it underestimates the observed variability. The model overestimates the observed $\mathrm{Hg}^{0}$ concentrations in the southern hemisphere by about 20 ppq but this could reflect uncertainty in ocean $\mathrm{Hg}^{0}$ emissions. ${ }^{33}$

SI Figure S6 compares the simulated and observed $\mathrm{Hg}^{0}$ concentrations in surface air for different latitudinal bands. Polar concentrations show a spring minimum both in the observations and in the model due to high bromine in the polar MBL. ${ }^{12,95}$ Observations at northern midlatitudes show minimum concentrations in summer-fall, previously attributed in GEOS-Chem to oxidation by $\mathrm{OH}$ and $\mathrm{Br}^{21,57}$ but here the model minimum is shifted to spring because of the large $\mathrm{Br}$ source from SSA debromination. ${ }^{82}$ There is no significant seasonal variation in the tropics either in the model or in the observations. Observations at southern midlatitudes also show no significant seasonal variation but the model has a summer minimum driven by $\mathrm{Hg}^{0}$ oxidation. Interpretation of model errors in reproducing the observed $\mathrm{Hg}^{0}$ seasonal variations is complicated by uncertainties in the seasonality of ocean and land fluxes. ${ }^{42}$

Simulated $\mathrm{Hg}^{\mathrm{II}}$ concentrations increase with altitude in the troposphere-from $1 \mathrm{ppq}$ in surface air to $15 \mathrm{ppq}$ at the tropopause-reflecting the sink from deposition. Concentrations are highest in the subtropics due to subsidence of $\mathrm{Hg}^{\mathrm{II}}$ produced in the tropical upper troposphere. ${ }^{96,97}$ Values in surface air are consistent with long-term $\mathrm{Hg}^{\mathrm{II}}$ observations made using $\mathrm{KCl}$-coated denuders (SI Figure S7), but these measurements are known to be biased low. ${ }^{9899}$ Aircraft measurements find an average of $10 \mathrm{ppq} \mathrm{Hg}^{\mathrm{II}}$ in the free troposphere at northern midlatitudes, ${ }^{5}$ much higher than in the model (Figure 3 ). Using the higher $\mathrm{Br}$ concentrations from Schmidt et al. ${ }^{80}$ in the model does not fix the problem, but

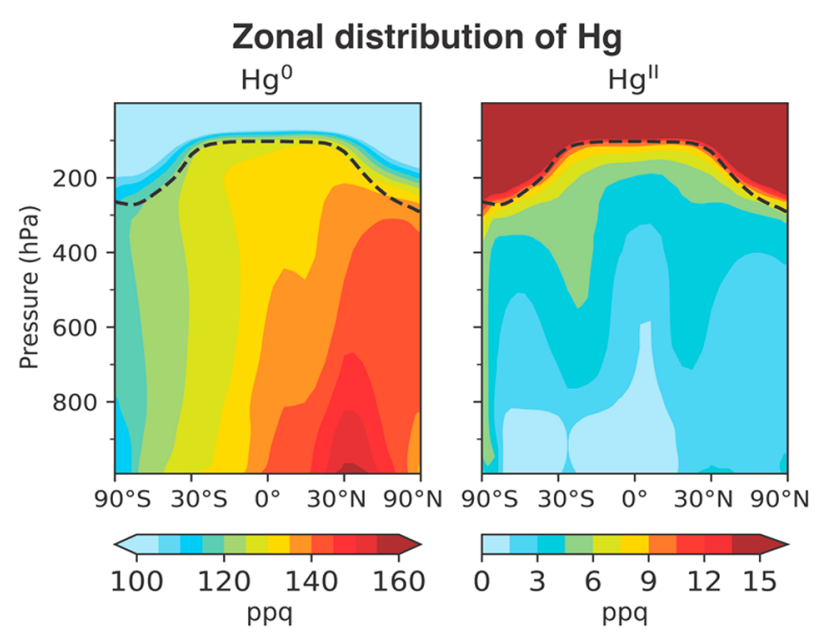

Surface $\mathrm{Hg}^{0}$ concentrations
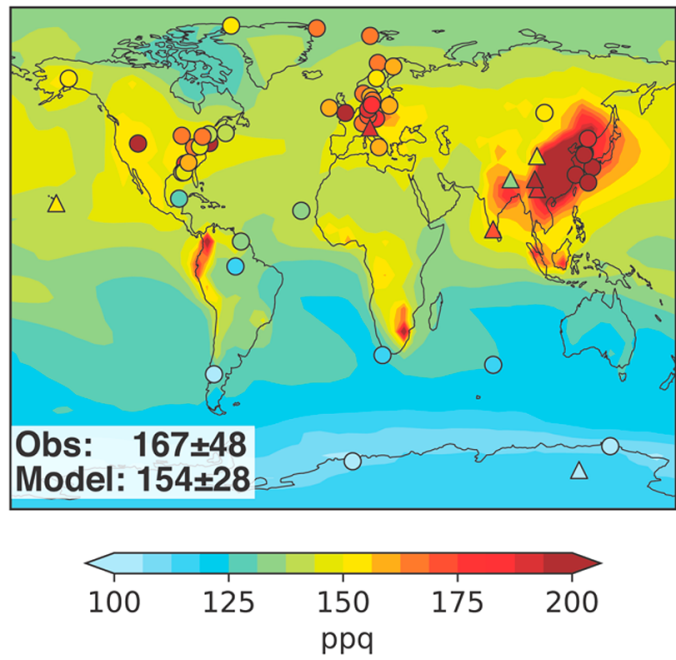

Figure 3. Annual mean (2013-2015) concentrations of $\mathrm{Hg}^{0}$ and $\mathrm{Hg}^{\mathrm{II}}$ in GEOS-Chem. The top panels are zonal mean concentrations as a function of pressure and sine latitude. The dashed lines indicate the annual mean tropopause. The bottom panel compares the modeled surface $\mathrm{Hg}^{0}$ concentrations with observations (filled circles and triangles) from the compilations of Travnikov et al. ${ }^{51}$ (courtesy of Hélène Angot) and AMAP/UNEP. ${ }^{114}$ Filled triangles represent high altitude sites. We only include observations made between 2010 and 2015. The mean \pm standard deviation of the observed concentrations is inset in the bottom panel along with the corresponding model values sampled at the site locations. The color scales are different for each panel.

slower aqueous photoreduction would. We conducted a sensitivity simulation in which aqueous $\mathrm{Hg}^{\mathrm{II}}$ photoreduction was limited to liquid cloud droplets and $\mathrm{Hg}^{\mathrm{II}} \mathrm{P}$ (org) formation on aerosol particles was excluded, similar to Saiz-Lopez et al., ${ }^{1,5}$ and found a doubling of $\mathrm{Hg}^{\mathrm{II}}$ concentrations in the free troposphere. However, $\mathrm{Hg}^{\mathrm{II}} \mathrm{P}$ (org) photoreduction frequency in cloud droplets required to fit the observed $\mathrm{Hg}$ lifetime against deposition in that sensitivity simulation was much higher and inconsistent with the rainwater observations of SaizLopez et al. ${ }^{1}$

Figure 4 shows the observed and modeled $\mathrm{Hg}^{\mathrm{II}}$ wet deposition fluxes, as well as the modeled total (wet + dry) $\mathrm{Hg}^{\mathrm{II}}$ deposition flux. The mean $\mathrm{Hg}$ wet deposition flux for the global ensemble of sites is $25 \%$ lower in the model than in the observations. The model shows maximum wet deposition flux 

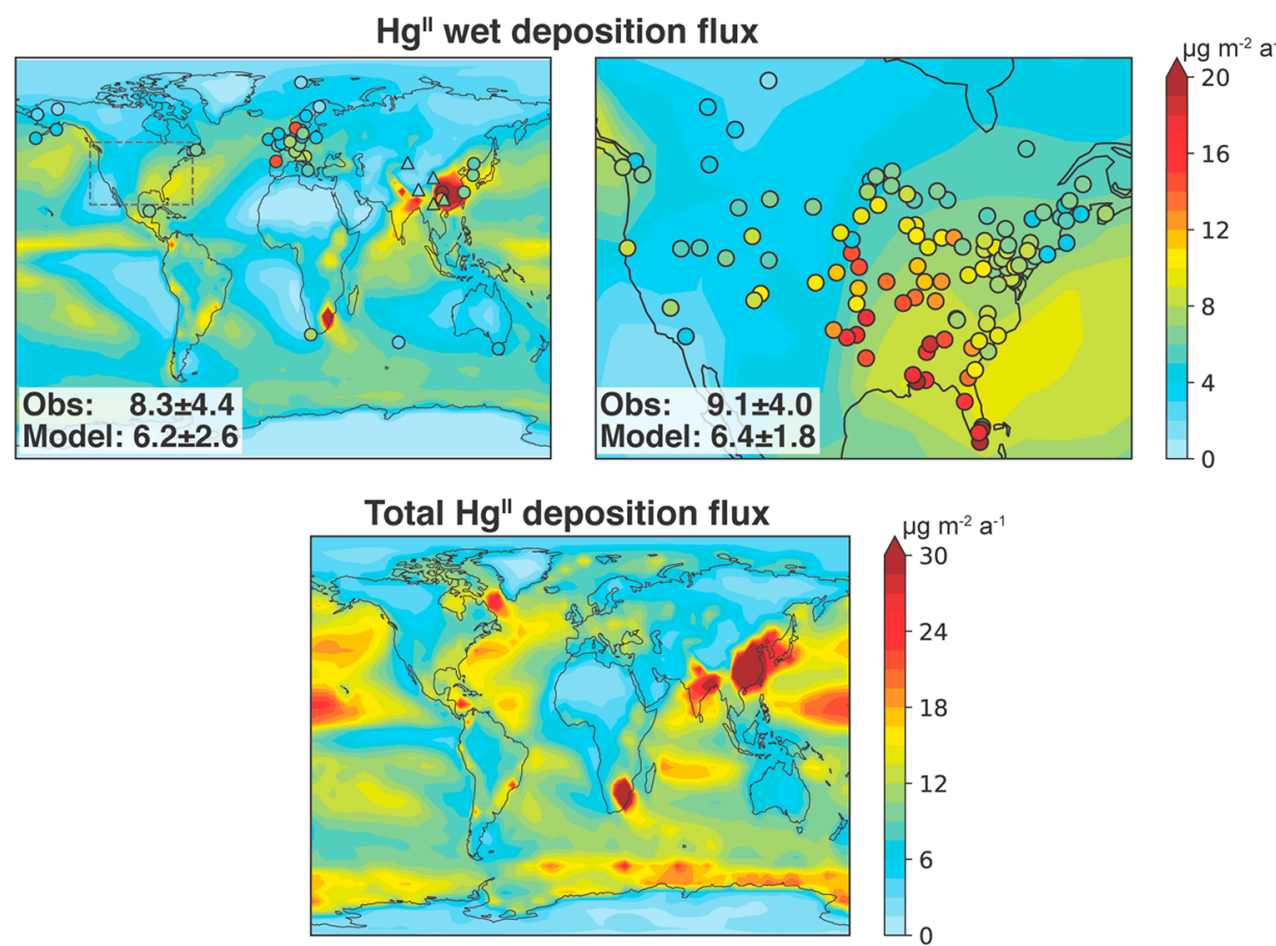

Figure 4. Annual mean (2013-2015) $\mathrm{Hg}^{\mathrm{II}}$ deposition fluxes in GEOS-Chem. The top panels show $\mathrm{Hg}^{\mathrm{II}}$ wet deposition fluxes overlaid by observations (filled circles and triangles) compiled by Travnikov et al. ${ }^{51}$ (courtesy of Hélène Angot), Sprovieri et al., ${ }^{113}$ AMAP/UNEP, ${ }^{114}$ and Fu et al. ${ }^{116}$ Filled triangles represent high altitude sites. We only include observations collected between 2010 and 2015 . Values inset are the means \pm standard deviations for the global ensemble of sites (left panel) and for the subset of sites over the contiguous U.S. and Canada (right panel). The bottom panel shows total (wet + dry) $\mathrm{Hg}^{\mathrm{II}}$ deposition fluxes.

over eastern China because of high anthropogenic $\mathrm{Hg}^{\mathrm{II}}$ emissions, but this is not seen in observations, suggesting that China's $\mathrm{Hg}^{\mathrm{II}}$ emissions may be overestimated due to insufficient accounting of recent emission controls. ${ }^{100}$ The model captures the regional maximum of $\mathrm{Hg}^{\mathrm{II}}$ wet deposition over the southeast U.S. driven by deep convective scavenging of free tropospheric $\mathrm{Hg}^{\mathrm{II}}$-rich air, ${ }^{101-103}$ but underestimates its magnitude because of the previously discussed underestimate of $\mathrm{Hg}^{\mathrm{II}}$ in the free troposphere.

The global $\mathrm{Hg}^{\mathrm{II}}$ wet deposition flux in our standard simulation is $2.6 \mathrm{Gg} \mathrm{a}^{-1}$ and the total (wet + dry) $\mathrm{Hg}^{\mathrm{II}}$ deposition flux is $5.5 \mathrm{Gg} \mathrm{a}^{-1}$. Another $1.2 \mathrm{Gg} \mathrm{a}^{-1}$ is dry deposited to land as $\mathrm{Hg}^{0}$. We find that $71 \%$ of $\mathrm{Hg}^{\mathrm{II}}$ deposition takes place over the oceans, where it is the main source of $\mathrm{Hg}$ for the marine biosphere, ${ }^{104,105}$ and is $15 \%$ higher in the northern than in the southern hemisphere. Horowitz et al. ${ }^{33}$ found a higher fraction ( $82 \%$ ) of $\mathrm{Hg}^{\mathrm{II}}$ deposition over the oceans because of faster $\mathrm{Hg}^{\mathrm{II}}$ reduction over land driven by high organic aerosol. Holmes et al. ${ }^{57}$ found that $72 \%$ of the $\mathrm{Hg}^{\text {II }}$ deposition takes place over the oceans, but with a higher flux in the southern hemisphere than in the northern hemisphere, reflecting the $\mathrm{Br}$ distribution in their simulation. $\mathrm{Hg}^{\mathrm{II}}$ deposition over land in our simulation is concentrated largely in $\mathrm{Hg}^{\mathrm{II}}$ emission hotspots over China, India, and South Africa. Outside of these hotspots, $\mathrm{Hg}^{0}$ dry deposition is the major route for $\mathrm{Hg}$ deposition over land, contributing $45 \%$ globally, but lower than observational estimates of 50$90 \% .^{106,107}$

Uncertainties in Atmospheric Hg Redox Chemistry. We have aimed to provide a mechanistic representation of $\mathrm{Hg}$ redox cycling in the atmosphere that reflects current chemical knowledge while being consistent with fundamental observa- tional constraints. This involved a number of assumptions and here we examine the most consequential.

An important uncertainty is the oxidation rate of $\mathrm{Hg}^{0}$ by $\mathrm{Br}$, reflecting both the reaction rate coefficient and the $\mathrm{Br}$ concentrations. Laboratory determinations of the $\mathrm{Hg}^{0}+\mathrm{Br}$ rate coefficient vary from $3.6 \times 10^{-13}$ to $3.2 \times 10^{-12} \mathrm{~cm}^{3}$ molec $^{-1} \mathrm{~s}^{-1}$ (at $\left.298 \mathrm{~K}, 1 \mathrm{~atm}\right) .{ }^{44,45,108}$ We use the rate coefficient from Donohoue et al., ${ }^{45}$ which is at the low end, because their measurements are least affected by wall reactions and were made over a range of pressures and temperatures. Using a higher value would require slower conversion of $\mathrm{BrHg}^{\mathrm{I}}$ to $\mathrm{Hg}^{\mathrm{II}}$, faster $\mathrm{Hg}^{\mathrm{II}}$ reduction, and/or lower $\mathrm{Br}$ concentrations to maintain the same $\mathrm{Hg}$ lifetime against deposition in the model. The $\mathrm{BrHg}^{\mathrm{I}} \rightarrow \mathrm{Hg}^{\mathrm{II}}$ rate can be slowed by lowering the $\mathrm{BrHg}^{\mathrm{I}}+\mathrm{O}_{3}$ and increasing the $\mathrm{BrHg}^{\mathrm{I}} \mathrm{O}+\mathrm{CO}$ rate coefficients, and while the changes needed are substantial (factor of 10) since the competing $\mathrm{BrHg}^{\mathrm{I}} \rightarrow \mathrm{Hg}^{0}$ reactions are currently negligible, they would be within the uncertainties of the theoretically derived rate coefficients. ${ }^{109}$ Faster $\mathrm{Hg}^{\mathrm{II}}$ reduction would still need to fit the observed rainwater photoreduction rates. ${ }^{1,37}$ Faster $\mathrm{Hg}^{0}+\mathrm{Br}$ kinetics could be offset by lower $\mathrm{Br}$ concentrations, but the concentrations used here are at the low end of current models as discussed by Wang et al. ${ }^{34,58}$

The atmospheric $\mathrm{OH}$ concentrations are well-known ${ }^{110}$ and the $\mathrm{Hg}^{0}+\mathrm{OH}$ rate coefficient agrees between two independent laboratory studies, ${ }^{54,55}$ although the pressure and temperature dependences of the rate coefficient need to be further investigated. There are large uncertainties in the $\mathrm{HOHg}^{\mathrm{I}}+\mathrm{M}$, $\mathrm{HOHg}^{\mathrm{I}}+\mathrm{O}_{3}, \mathrm{HOHg}^{\mathrm{II}} \mathrm{O}+\mathrm{CO}$, and $\mathrm{HOHg}^{\mathrm{II}} \mathrm{O}+\mathrm{CH}_{4}$ reactions that control the branching between $\mathrm{HOHg}^{\mathrm{I}} \rightarrow \mathrm{Hg}^{0}$ and $\mathrm{HOHg}^{\mathrm{I}} \rightarrow \mathrm{Hg}^{\mathrm{II}}(\mathrm{OH})_{2}$. The $\mathrm{HOHg}^{\mathrm{I}}+\mathrm{M}$ rate coefficient depends on the $\mathrm{HO}-\mathrm{Hg}^{\mathrm{I}}$ bond strength, which has not been 
determined experimentally. ${ }^{6}$ A moderate change in this rate coefficient could be balanced by proportional changes in the rate coefficients of the other three reactions. Slower dissociation of $\mathrm{HOHg}^{\mathrm{I}}$ (stronger bond) would increase net $\mathrm{Hg}^{0}$ oxidation in the subtropical free troposphere and help improve the simulation of the observed $\mathrm{Hg}$ wet deposition flux maximum over the southeast U.S.

An important part of our mechanism is the photoreduction of $\mathrm{Hg}^{\mathrm{II}}$-organic complexes in aerosols but there are no direct data to inform the photoreduction rates. Here we have assumed similarity with photoreduction in cloud droplets, which is informed (though weakly so) by the rainwater photoreduction data. ${ }^{1,35}$ Dissolved organic carbon is known to be critical for $\mathrm{Hg}^{\mathrm{II}}$ photoreduction in aquatic systems, ${ }^{70-72}$ but there is no knowledge of the relevant organic ligands for atmospheric $\mathrm{Hg}^{\mathrm{II}}$. A better understanding of particulate and cloud $\mathrm{Hg}^{\mathrm{II}}$ speciation, and the implications for photoreduction, would greatly advance our modeling capability.

\section{ASSOCIATED CONTENT}

\section{(3) Supporting Information}

The Supporting Information is available free of charge at https://pubs.acs.org/doi/10.1021/acs.est.1c03160.

Energy profiles for the $\mathrm{BrHg}^{\mathrm{I}}+\mathrm{O}_{3}$ reaction (Figure S1); Preliminary rate coefficient for $\mathrm{BrHg}^{\mathrm{I}}+\mathrm{O}_{3}$ as a function of temperature (Figure S2); Potential energy surface for the $\mathrm{HOHg}+\mathrm{O}_{3}$ reaction (Figure S3); Comparison of the zonal mean $\mathrm{Br}$ and $\mathrm{BrO}$ concentrations in GEOS-Chem version 12.9 and from Schmidt et al. (Figure S4); Main $\mathrm{Hg}$ redox pathways and the zonal distribution of $\mathrm{Hg}^{0}$ and $\mathrm{Hg}^{\mathrm{II}}$ in the simulation with the Schmidt et al. Br concentration (Figure S5); Observed and modeled seasonal variation of surface $\mathrm{Hg}^{0}$ concentrations (Figure $\mathrm{S6})$; and Observed and modeled annual surface $\mathrm{Hg}^{\mathrm{II}}$ concentrations (Figure S7) (PDF)

\section{AUTHOR INFORMATION}

\section{Corresponding Author}

Viral Shah - Harvard John A. Paulson School of Engineering and Applied Sciences, Harvard University, Cambridge, Massachusetts 02138, United States; (1) orcid.org/00000001-5547-106X; Email: vshah@seas.harvard.edu

\section{Authors}

Daniel J. Jacob - Harvard John A. Paulson School of Engineering and Applied Sciences and Department of Earth and Planetary Sciences, Harvard University, Cambridge, Massachusetts 02138, United States

Colin P. Thackray - Harvard John A. Paulson School of Engineering and Applied Sciences, Harvard University, Cambridge, Massachusetts 02138, United States

Xuan Wang - School of Energy and Environment, City University of Hong Kong, Hong Kong SAR, China; (1) orcid.org/0000-0002-8532-5773

Elsie M. Sunderland - Harvard John A. Paulson School of Engineering and Applied Sciences, Harvard University, Cambridge, Massachusetts 02138, United States; Department of Environmental Health, Harvard T.H. Chan School of Public Health, Harvard University, Boston, Massachusetts 02115, United States; (1) orcid.org/00000003-0386-9548
Theodore S. Dibble - Department of Chemistry, State University of New York, College of Environmental Science and Forestry, Syracuse, New York 13210, United States; - orcid.org/0000-0002-0023-8233

Alfonso Saiz-Lopez - Department of Atmospheric Chemistry and Climate, Institute of Physical Chemistry Rocasolano, CSIC, Madrid 28006, Spain; 이이.org/0000-00020060-1581

Ivan Cernusák - Department of Physical and Theoretical Chemistry, Faculty of Natural Sciences, Comenius University in Bratislava, 84215 Bratislava, Slovakia; orcid.org/ 0000-0002-6597-3095

Vladimir Kellö - Department of Physical and Theoretical Chemistry, Faculty of Natural Sciences, Comenius University in Bratislava, 84215 Bratislava, Slovakia

Pedro J. Castro - Department of Chemistry, State University of New York, College of Environmental Science and Forestry, Syracuse, New York 13210, United States

Rongrong Wu - Department of Physics and Astronomy, Mississippi State University, Starkville, Mississippi 39759, United States

Chuji Wang - Department of Physics and Astronomy, Mississippi State University, Starkville, Mississippi 39759, United States

Complete contact information is available at: https://pubs.acs.org/10.1021/acs.est.1c03160

\section{Author Contributions}

V.S. and D.J.J. developed the chemical mechanism with input from C.P.T., E.M.S., T.S.D., and A.S.-L.; V.S. and C.P.T. implemented the mechanism in GEOS-Chem; X.W. developed the current GEOS-Chem halogen simulation; T.S.D, I.Č, V.K, and P.J.C. performed the quantum chemistry calculations for the reactions of $\mathrm{BrHg}$ and $\mathrm{HOHg}$ with ozone; R.W. and C.W. conducted laboratory experiments on the $\mathrm{BrHg}$ and ozone reaction; V.S. and D.J.J. wrote the manuscript with contributions from all coauthors.

Notes

The authors declare no competing financial interest.

\section{ACKNOWLEDGMENTS}

This work was funded by the USEPA Science to Achieve Results (STAR) Program. This work was also supported by the Slovak Grant Agency VEGA (grant 1/0777/19), the highperformance computing facility of the Centre for Information Technology (https://uniba.sk/en/HPC-Clara) at Comenius University, and the U.S. National Science Foundation under awards 1609848 and 2004100. We thank Hélène Angot (CU Boulder) for the $\mathrm{Hg}$ measurement data.

\section{REFERENCES}

(1) Saiz-Lopez, A.; Sitkiewicz, S. P.; Roca-Sanjuán, D.; Oliva-Enrich, J. M.; Dávalos, J. Z.; Notario, R.; Jiskra, M.; Xu, Y.; Wang, F.; Thackray, C. P.; Sunderland, E. M.; Jacob, D. J.; Travnikov, O.; Cuevas, C. A.; Acuña, A. U.; Rivero, D.; Plane, J. M. C.; Kinnison, D. E.; Sonke, J. E. Photoreduction of Gaseous Oxidized Mercury Changes Global Atmospheric Mercury Speciation, Transport and Deposition. Nat. Commun. 2018, 9 (1), 4796.

(2) Lam, K. T.; Wilhelmsen, C. J.; Schwid, A. C.; Jiao, Y.; Dibble, T. S. Computational Study on the Photolysis of $\mathrm{BrHgONO}$ and the Reactions of $\mathrm{BrHgO}^{\bullet}$ with $\mathrm{CH}_{4}, \mathrm{C}_{2} \mathrm{H}_{6}, \mathrm{NO}$, and $\mathrm{NO}_{2}$ : Implications for Formation of $\mathrm{Hg}(\mathrm{II})$ Compounds in the Atmosphere. J. Phys. Chem. A 2019, 123 (8), 1637-1647. 
(3) Francés-Monerris, A.; Carmona-García, J.; Acuña, A. U.; Dávalos, J. Z.; Cuevas, C. A.; Kinnison, D. E.; Francisco, J. S.; SaizLopez, A.; Roca-Sanjuán, D. Photodissociation Mechanisms of Major Mercury(II) Species in the Atmospheric Chemical Cycle of Mercury. Angew. Chem., Int. Ed. 2020, 59 (19), 7605-7610.

(4) Khiri, D.; Louis, F.; Černušák, I.; Dibble, T. S. $\mathrm{BrHgO}^{\bullet}+\mathrm{CO}$ Analogue of $\mathrm{OH}+\mathrm{CO}$ and Reduction Path for $\mathrm{Hg}(\mathrm{II})$ in the Atmosphere. ACS Earth Space Chem. 2020, 4 (10), 1777-1784.

(5) Saiz-Lopez, A.; Travnikov, O.; Sonke, J. E.; Thackray, C. P.; Jacob, D. J.; Carmona-García, J.; Francés-Monerris, A.; Roca-Sanjuán, D.; Acuña, A. U.; Dávalos, J. Z.; Cuevas, C. A.; Jiskra, M.; Wang, F.; Bieser, J.; Plane, J. M. C.; Francisco, J. S. Photochemistry of Oxidized $\mathrm{Hg}(\mathrm{I})$ and $\mathrm{Hg}$ (II) Species Suggests Missing Mercury Oxidation in the Troposphere. Proc. Natl. Acad. Sci. U. S. A. 2020, 117 (49), 3094930956.

(6) Dibble, T. S.; Tetu, H. L.; Jiao, Y.; Thackray, C. P.; Jacob, D. J. Modeling the $\mathrm{OH}$-Initiated Oxidation of Mercury in the Global Atmosphere without Violating Physical Laws. J. Phys. Chem. A 2020, 124 (2), 444-453.

(7) Pirrone, N.; Cinnirella, S.; Feng, X.; Finkelman, R. B.; Friedli, H. R.; Leaner, J.; Mason, R.; Mukherjee, A. B.; Stracher, G. B.; Streets, D. G.; Telmer, K. Global Mercury Emissions to the Atmosphere from Anthropogenic and Natural Sources. Atmos. Chem. Phys. 2010, 10 (13), 5951-5964.

(8) Streets, D. G.; Horowitz, H. M.; Lu, Z.; Levin, L.; Thackray, C. P.; Sunderland, E. M. Five Hundred Years of Anthropogenic Mercury: Spatial and Temporal Release Profiles. Environ. Res. Lett. 2019, 14 (8), 084004.

(9) Jaffe, D. A.; Lyman, S.; Amos, H. M.; Gustin, M. S.; Huang, J.; Selin, N. E.; Levin, L.; ter Schure, A.; Mason, R. P.; Talbot, R.; Rutter, A.; Finley, B.; Jaeglé, L.; Shah, V.; McClure, C.; Ambrose, J.; Gratz, L.; Lindberg, S.; Weiss-Penzias, P.; Sheu, G.-R.; Feddersen, D.; Horvat, M.; Dastoor, A.; Hynes, A. J.; Mao, H.; Sonke, J. E.; Slemr, F.; Fisher, J. A.; Ebinghaus, R.; Zhang, Y.; Edwards, G. Progress on Understanding Atmospheric Mercury Hampered by Uncertain Measurements. Environ. Sci. Technol. 2014, 48 (13), 7204-7206.

(10) Gustin, M. S.; Amos, H. M.; Huang, J.; Miller, M. B.; Heidecorn, K. Measuring and Modeling Mercury in the Atmosphere: A Critical Review. Atmos. Chem. Phys. 2015, 15 (10), 5697-5713.

(11) Gustin, M. S.; Dunham-Cheatham, S. M.; Huang, J.; Lindberg, S.; Lyman, S. N. Development of an Understanding of Reactive Mercury in Ambient Air: A Review. Atmosphere 2021, 12 (1), 73.

(12) Lindberg, S. E.; Brooks, S.; Lin, C.-J.; Scott, K. J.; Landis, M. S.; Stevens, R. K.; Goodsite, M.; Richter, A. Dynamic Oxidation of Gaseous Mercury in the Arctic Troposphere at Polar Sunrise. Environ. Sci. Technol. 2002, 36 (6), 1245-1256.

(13) Holmes, C. D.; Jacob, D. J.; Yang, X. Global Lifetime of Elemental Mercury against Oxidation by Atomic Bromine in the Free Troposphere. Geophys. Res. Lett. 2006, 33 (20), L20808.

(14) Obrist, D.; Tas, E.; Peleg, M.; Matveev, V.; Faïn, X.; Asaf, D.; Luria, M. Bromine-Induced Oxidation of Mercury in the Mid-Latitude Atmosphere. Nat. Geosci. 2011, 4 (1), 22-26.

(15) Gratz, L. E.; Ambrose, J. L.; Jaffe, D. A.; Shah, V.; Jaeglé, L.; Stutz, J.; Festa, J.; Spolaor, M.; Tsai, C.; Selin, N. E.; Song, S.; Zhou, X.; Weinheimer, A. J.; Knapp, D. J.; Montzka, D. D.; Flocke, F. M.; Campos, T. L.; Apel, E.; Hornbrook, R.; Blake, N. J.; Hall, S.; Tyndall, G. S.; Reeves, M.; Stechman, D.; Stell, M. Oxidation of Mercury by Bromine in the Subtropical Pacific Free Troposphere. Geophys. Res. Lett. 2015, 42 (23), 10,494-10,502.

(16) Tossell, J. A. Calculation of the Energetics for Oxidation of Gas-Phase Elemental $\mathrm{Hg}$ by $\mathrm{Br}$ and BrO. J. Phys. Chem. A 2003, 107 (39), 7804-7808.

(17) Goodsite, M. E.; Plane, J. M. C.; Skov, H. A Theoretical Study of the Oxidation of $\mathrm{Hg}^{0}$ to $\mathrm{HgBr}_{2}$ in the Troposphere. Environ. Sci. Technol. 2004, 38 (6), 1772-1776.

(18) Goodsite, M. E.; Plane, J. M. C.; Skov, H. Correction to A Theoretical Study of the Oxidation of $\mathrm{Hg}^{0}$ to $\mathrm{HgBr}_{2}$ in the Troposphere. Environ. Sci. Technol. 2012, 46 (9), 5262-5262.
(19) Dibble, T. S.; Zelie, M. J.; Mao, H. Thermodynamics of Reactions of $\mathrm{ClHg}$ and $\mathrm{BrHg}$ Radicals with Atmospherically Abundant Free Radicals. Atmos. Chem. Phys. 2012, 12 (21), $10271-10279$.

(20) Lam, K. T.; Wilhelmsen, C. J.; Dibble, T. S. BrHgO $+\mathrm{C}_{2} \mathrm{H}_{4}$ and $\mathrm{BrHgO}^{\bullet}+\mathrm{HCHO}$ in Atmospheric Oxidation of Mercury: Determining Rate Constants of Reactions with Prereactive Complexes and Bifurcation. J. Phys. Chem. A 2019, 123 (28), 6045-6055.

(21) Selin, N. E.; Jacob, D. J.; Park, R. J.; Yantosca, R. M.; Strode, S.; Jaeglé, L.; Jaffe, D. Chemical Cycling and Deposition of Atmospheric Mercury: Global Constraints from Observations. J. Geophys. Res. 2007, 112 (D2). DOI: 10.1029/2006JD007450.

(22) Travnikov, O.; Ilyin, I. The EMEP/MSC-E Mercury Modeling System. In Mercury Fate and Transport in the Global Atmosphere; Mason, R., Pirrone, N., Eds.; Springer US: Boston, MA, 2009; pp 571-587. DOI: 10.1007/978-0-387-93958-2 20.

(23) De Simone, F.; Gencarelli, C. N.; Hedgecock, I. M.; Pirrone, N. Global Atmospheric Cycle of Mercury: A Model Study on the Impact of Oxidation Mechanisms. Environ. Sci. Pollut. Res. 2014, 21 (6), $4110-4123$.

(24) Dastoor, A.; Ryzhkov, A.; Durnford, D.; Lehnherr, I.; Steffen, A.; Morrison, H. Atmospheric Mercury in the Canadian Arctic. Part II: Insight from Modeling. Sci. Total Environ. 2015, 509-510, 16-27.

(25) Calvert, J.; Lindberg, S. Mechanisms of Mercury Removal by $\mathrm{O}_{3}$ and $\mathrm{OH}$ in the Atmosphere. Atmos. Environ. 2005, 39 (18), 33553367.

(26) Pal, B.; Ariya, P. A. Studies of Ozone Initiated Reactions of Gaseous Mercury: Kinetics, Product Studies, and Atmospheric Implications. Phys. Chem. Chem. Phys. 2004, 6 (3), 572.

(27) Sumner, A. L.; Spicer, C. W.; Satola, J.; Mangaraj, R.; Cowen, K. A.; Landis, M. S.; Stevens, R. K.; Atkeson, T. D. Environmental Chamber Studies of Mercury Reactions in the Atmosphere. In Dynamics of Mercury Pollution on Regional and Global Scales; Pirrone, N., Mahaffey, K. R., Eds.; Springer-Verlag: New York, 2005; pp 193212. DOI: $10.1007 / 0-387-24494-89$.

(28) Raofie, F.; Ariya, P. A. Product Study of the Gas-Phase BrOInitiated Oxidation of $\mathrm{Hg}^{0}$ : Evidence for Stable $\mathrm{Hg}^{1+}$ Compounds. Environ. Sci. Technol. 2004, 38 (16), 4319-4326.

(29) Shepler, B. C.; Peterson, K. A. Mercury Monoxide: A Systematic Investigation of Its Ground Electronic State. J. Phys. Chem. A 2003, 107 (11), 1783-1787.

(30) Filatov, M.; Cremer, D. Revision of the Dissociation Energies of Mercury Chalcogenides-Unusual Types of Mercury Bonding. ChemPhysChem 2004, 5 (10), 1547-1557.

(31) Peterson, K. A.; Shepler, B. C.; Singleton, J. M. The Group 12 Metal Chalcogenides: An Accurate Multireference Configuration Interaction and Coupled Cluster Study. Mol. Phys. 2007, 105 (9), $1139-1155$

(32) Donohoue, D. L.; Bauer, D.; Hynes, A. J. Temperature and Pressure Dependent Rate Coefficients for the Reaction of $\mathrm{Hg}$ with $\mathrm{Cl}$ and the Reaction of $\mathrm{Cl}$ with $\mathrm{Cl}$ : A Pulsed Laser Photolysis-Pulsed Laser Induced Fluorescence Study. J. Phys. Chem. A 2005, 109 (34), $7732-7741$.

(33) Horowitz, H. M.; Jacob, D. J.; Zhang, Y.; Dibble, T. S.; Slemr, F.; Amos, H. M.; Schmidt, J. A.; Corbitt, E. S.; Marais, E. A.; Sunderland, E. M. A New Mechanism for Atmospheric Mercury Redox Chemistry: Implications for the Global Mercury Budget. Atmos. Chem. Phys. 2017, 17 (10), 6353-6371.

(34) Wang, X.; Jacob, D. J.; Eastham, S. D.; Sulprizio, M. P.; Zhu, L.; Chen, Q.; Alexander, B.; Sherwen, T.; Evans, M. J.; Lee, B. H.; Haskins, J. D.; Lopez-Hilfiker, F. D.; Thornton, J. A.; Huey, G. L.; Liao, H. The Role of Chlorine in Global Tropospheric Chemistry. Atmos. Chem. Phys. 2019, 19 (6), 3981-4003.

(35) Amos, H. M.; Jacob, D. J.; Holmes, C. D.; Fisher, J. A.; Wang, Q.; Yantosca, R. M.; Corbitt, E. S.; Galarneau, E.; Rutter, A. P.; Gustin, M. S.; Steffen, A.; Schauer, J. J.; Graydon, J. A.; Louis, V. L. St.; Talbot, R. W.; Edgerton, E. S.; Zhang, Y.; Sunderland, E. M. GasParticle Partitioning of Atmospheric $\mathrm{Hg}$ (II) and Its Effect on Global Mercury Deposition. Atmos. Chem. Phys. 2012, 12 (1), 591-603. 
(36) Lin, C.-J.; Pehkonen, S. O. The Chemistry of Atmospheric Mercury: A Review. Atmos. Environ. 1999, 33 (13), 2067-2079.

(37) Yang, X.; Jiskra, M.; Sonke, J. E. Experimental Rainwater Divalent Mercury Speciation and Photoreduction Rates in the Presence of Halides and Organic Carbon. Sci. Total Environ. 2019, 697, 133821.

(38) Strode, S. A.; Jaeglé, L.; Selin, N. E.; Jacob, D. J.; Park, R. J.; Yantosca, R. M.; Mason, R. P.; Slemr, F. Air-Sea Exchange in the Global Mercury Cycle. Global Biogeochem. Cycles 2007, 21 (1), GB1017.

(39) Selin, N. E.; Jacob, D. J.; Yantosca, R. M.; Strode, S.; Jaeglé, L.; Sunderland, E. M. Global 3-D Land-Ocean-Atmosphere Model for Mercury: Present-Day versus Preindustrial Cycles and Anthropogenic Enrichment Factors for Deposition. Global Biogeochem. Cycles 2008, 22 (2), GB2011.

(40) Soerensen, A. L.; Sunderland, E. M.; Holmes, C. D.; Jacob, D. J.; Yantosca, R. M.; Skov, H.; Christensen, J. H.; Strode, S. A.; Mason, R. P. An Improved Global Model for Air-Sea Exchange of Mercury: High Concentrations over the North Atlantic. Environ. Sci. Technol. 2010, 44 (22), 8574-8580.

(41) Smith-Downey, N. V.; Sunderland, E. M.; Jacob, D. J. Anthropogenic Impacts on Global Storage and Emissions of Mercury from Terrestrial Soils: Insights from a New Global Model. J. Geophys. Res. 2010, 115 (G3), G03008.

(42) Song, S.; Selin, N. E.; Soerensen, A. L.; Angot, H.; Artz, R.; Brooks, S.; Brunke, E.-G.; Conley, G.; Dommergue, A.; Ebinghaus, R.; Holsen, T. M.; Jaffe, D. A.; Kang, S.; Kelley, P.; Luke, W. T.; Magand, O.; Marumoto, K.; Pfaffhuber, K. A.; Ren, X.; Sheu, G.-R.; Slemr, F.; Warneke, T.; Weigelt, A.; Weiss-Penzias, P.; Wip, D. C.; Zhang, Q. Top-down Constraints on Atmospheric Mercury Emissions and Implications for Global Biogeochemical Cycling. Atmos. Chem. Phys. 2015, 15 (12), 7103-7125.

(43) Balabanov, N. B.; Shepler, B. C.; Peterson, K. A. Accurate Global Potential Energy Surface and Reaction Dynamics for the Ground State of $\mathrm{HgBr}_{2}$. J. Phys. Chem. A 2005, 109 (39), 8765-8773.

(44) Ariya, P. A.; Khalizov, A.; Gidas, A. Reactions of Gaseous Mercury with Atomic and Molecular Halogens: Kinetics, Product Studies, and Atmospheric Implications. J. Phys. Chem. A 2002, 106 (32), 7310-7320.

(45) Donohoue, D. L.; Bauer, D.; Cossairt, B.; Hynes, A. J. Temperature and Pressure Dependent Rate Coefficients for the Reaction of $\mathrm{Hg}$ with $\mathrm{Br}$ and the Reaction of $\mathrm{Br}$ with $\mathrm{Br}$ : A Pulsed Laser Photolysis-Pulsed Laser Induced Fluorescence Study. J. Phys. Chem. A 2006, 110 (21), 6623-6632.

(46) Jiao, Y.; Dibble, T. S. First Kinetic Study of the Atmospherically Important Reactions $\mathrm{BrHg}^{\bullet}+\mathrm{NO}_{2}$ and $\mathrm{BrHg}^{\bullet}+\mathrm{HOO}$. Phys. Chem. Chem. Phys. 2017, 19 (3), 1826-1838.

(47) Jiao, Y.; Dibble, T. S. Structures, Vibrational Frequencies, and Bond Energies of the $\mathrm{BrHgOX}$ and $\mathrm{BrHgXO}$ Species Formed in Atmospheric Mercury Depletion Events. J. Phys. Chem. A 2017, 121 (41), 7976-7985.

(48) Dibble, T. S.; Schwid, A. C. Thermodynamics Limits the Reactivity of $\mathrm{BrHg}$ Radical with Volatile Organic Compounds. Chem. Phys. Lett. 2016, 659, 289-294.

(49) Shah, V.; Jaeglé, L.; Gratz, L. E.; Ambrose, J. L.; Jaffe, D. A.; Selin, N. E.; Song, S.; Campos, T. L.; Flocke, F. M.; Reeves, M.; Stechman, D.; Stell, M.; Festa, J.; Stutz, J.; Weinheimer, A. J.; Knapp, D. J.; Montzka, D. D.; Tyndall, G. S.; Apel, E. C.; Hornbrook, R. S.; Hills, A. J.; Riemer, D. D.; Blake, N. J.; Cantrell, C. A.; Mauldin, R. L., III Origin of Oxidized Mercury in the Summertime Free Troposphere over the Southeastern US. Atmos. Chem. Phys. 2016, 16 (3), 15111530.

(50) Wang, F.; Saiz-Lopez, A.; Mahajan, A. S.; Gómez Martín, J. C.; Armstrong, D.; Lemes, M.; Hay, T.; Prados-Roman, C. Enhanced Production of Oxidised Mercury Over the Tropical Pacific Ocean: A Key Missing Oxidation Pathway. Atmos. Chem. Phys. 2014, 14 (3), 1323-1335.

(51) Travnikov, O.; Angot, H.; Artaxo, P.; Bencardino, M.; Bieser, J.; D’Amore, F.; Dastoor, A.; De Simone, F.; Diéguez, M. del C.;
Dommergue, A.; Ebinghaus, R.; Feng, X. B.; Gencarelli, C. N.; Hedgecock, I. M.; Magand, O.; Martin, L.; Matthias, V.; Mashyanov, N.; Pirrone, N.; Ramachandran, R.; Read, K. A.; Ryjkov, A.; Selin, N. E.; Sena, F.; Song, S.; Sprovieri, F.; Wip, D.; Wängberg, I.; Yang, X. Multi-Model Study of Mercury Dispersion in the Atmosphere: Atmospheric Processes and Model Evaluation. Atmos. Chem. Phys. 2017, 17 (8), 5271-5295.

(52) Ye, Z.; Mao, H.; Driscoll, C. T.; Wang, Y.; Zhang, Y.; Jaeglé, L. Evaluation of CMAQ Coupled With a State-of-the-Art Mercury Chemical Mechanism (CMAQ-newHg-Br). J. Adv. Model. Earth Syst. 2018, 10 (3), 668-690.

(53) Wu, R.; Wang, C.; Dibble, T. S. First Experimental Kinetic Study of the Atmospherically Important Reaction of $\mathrm{BrHg}+\mathrm{NO}_{2}$. Chem. Phys. Lett. 2020, 759, 137928.

(54) Sommar, J.; Gårdfeldt, K.; Strömberg, D.; Feng, X. A Kinetic Study of the Gas-Phase Reaction Between the Hydroxyl Radical and Atomic Mercury. Atmos. Environ. 2001, 35 (17), 3049-3054.

(55) Pal, B.; Ariya, P. A. Gas-Phase $\mathrm{HO}^{\bullet}$-Initiated Reactions of Elemental Mercury: Kinetics, Product Studies, and Atmospheric Implications. Environ. Sci. Technol. 2004, 38 (21), 5555-5566.

(56) Hynes, A. J.; Donohoue, D. L.; Goodsite, M. E.; Hedgecock, I. M. Our Current Understanding of Major Chemical and Physical Processes Affecting Mercury Dynamics in the Atmosphere and at the Air-Water/Terrestrial Interfaces. In Mercury Fate and Transport in the Global Atmosphere; Mason, R., Pirrone, N., Eds.; Springer US: Boston, MA, 2009; pp 427-457. DOI: 10.1007/978-0-387-93958-2_14.

(57) Holmes, C. D.; Jacob, D. J.; Corbitt, E. S.; Mao, J.; Yang, X.; Talbot, R.; Slemr, F. Global Atmospheric Model for Mercury Including Oxidation by Bromine Atoms. Atmos. Chem. Phys. 2010, 10 (24), 12037-12057.

(58) Wang, X.; Jacob, D. J.; Downs, W.; Zhai, S.; Zhu, L.; Shah, V.; Holmes, C. D.; Sherwen, T.; Alexander, B.; Evans, M. J.; Eastham, S. D.; Neuman, J. A.; Veres, P.; Koenig, T. K.; Volkamer, R.; Huey, L. G.; Bannan, T. J.; Percival, C. J.; Lee, B. H.; Thornton, J. A. Global Tropospheric Halogen ( $\mathrm{Cl}, \mathrm{Br}, \mathrm{I})$ Chemistry and Its Impact on Oxidants. Atmos. Chem. Phys. Discuss. 2021. DOI: 10.5194/acp-2021441.

(59) Saiz-Lopez, A.; Acuña, A. U.; Trabelsi, T.; Carmona-García, J.; Dávalos, J. Z.; Rivero, D.; Cuevas, C. A.; Kinnison, D. E.; Sitkiewicz, S. P.; Roca-Sanjuán, D.; Francisco, J. S. Gas-Phase Photolysis of $\mathrm{Hg}(\mathrm{I})$ Radical Species: A New Atmospheric Mercury Reduction Process. J. Am. Chem. Soc. 2019, 141 (22), 8698-8702.

(60) Shepler, B. C.; Balabanov, N. B.; Peterson, K. A. $\mathrm{Hg}+\mathrm{Br} \rightarrow \mathrm{HgBr}$ Recombination and Collision-Induced Dissociation Dynamics. J. Chem. Phys. 2007, 127 (16), 164304.

(61) Lin, C.-J.; Pehkonen, S. O. Two-Phase Model of Mercury Chemistry in the Atmosphere. Atmos. Environ. 1998, 32 (14-15), $2543-2558$

(62) Hedgecock, I. M.; Pirrone, N. Mercury and Photochemistry in the Marine Boundary Layer-Modelling Studies Suggest the In Situ Production of Reactive Gas Phase Mercury. Atmos. Environ. 2001, 35 (17), 3055-3062.

(63) Haitzer, M.; Aiken, G. R.; Ryan, J. N. Binding of Mercury(II) to Dissolved Organic Matter: The Role of the Mercury-to-DOM Concentration Ratio. Environ. Sci. Technol. 2002, 36 (16), 35643570.

(64) Ravichandran, M. Interactions Between Mercury and Dissolved Organic Matter--A Review. Chemosphere 2004, 55 (3), 319-331.

(65) Munthe, J.; McElroy, W. J. Some Aqueous Reactions of Potential Importance in the Atmospheric Chemistry of Mercury. Atmos. Environ., Part A 1992, 26 (4), 553-557.

(66) Munthe, J.; Xiao, Z. F.; Lindqvist, O. The Aqueous Reduction of Divalent Mercury by Sulfite. Water, Air, Soil Pollut. 1991, 56 (1), 621-630.

(67) Pehkonen, S. O.; Lin, C.-J. Aqueous Photochemistry of Mercury with Organic Acids. J. Air Waste Manage. Assoc. 1998, 48 (2), 144-150. 
(68) Gårdfeldt, K.; Jonsson, M. Is Bimolecular Reduction of $\mathrm{Hg}$ (II) Complexes Possible in Aqueous Systems of Environmental Importance. J. Phys. Chem. A 2003, 107 (22), 4478-4482.

(69) Si, L.; Ariya, P. A. Reduction of Oxidized Mercury Species by Dicarboxylic Acids $\left(\mathrm{C}_{2}-\mathrm{C}_{4}\right)$ : Kinetic and Product Studies. Environ. Sci. Technol. 2008, 42 (14), 5150-5155.

(70) Amyot, M.; McQueen, D. J.; Mierle, G.; Lean, D. R. S. Sunlight-Induced Formation of Dissolved Gaseous Mercury in Lake Waters. Environ. Sci. Technol. 1994, 28 (13), 2366-2371.

(71) O’Driscoll, N. J.; Lean, D. R. S.; Loseto, L. L.; Carignan, R.; Siciliano, S. D. Effect of Dissolved Organic Carbon on the Photoproduction of Dissolved Gaseous Mercury in Lakes: Potential Impacts of Forestry. Environ. Sci. Technol. 2004, 38 (9), 2664-2672.

(72) Whalin, L.; Kim, E.-H.; Mason, R. Factors Influencing the Oxidation, Reduction, Methylation and Demethylation of Mercury Species in Coastal Waters. Mar. Chem. 2007, 107 (3), 278-294.

(73) Qureshi, A.; MacLeod, M.; Sunderland, E.; Hungerbühler, K. Exchange of Elemental Mercury between the Oceans and the Atmosphere. In Environmental Chemistry and Toxicology of Mercury; Liu, G., Cai, Y., O’Driscoll, N., Eds.; John Wiley \& Sons, Inc.: Hoboken, NJ, 2011; pp 389-421. DOI: 10.1002/ 9781118146644.ch12.

(74) Streets, D. G.; Horowitz, H. M.; Lu, Z.; Levin, L.; Thackray, C. P.; Sunderland, E. M. Global and Regional Trends in Mercury Emissions and Concentrations, 2010-2015. Atmos. Environ. 2019, 201, 417-427.

(75) Gelaro, R.; McCarty, W.; Suárez, M. J.; Todling, R.; Molod, A.; Takacs, L.; Randles, C. A.; Darmenov, A.; Bosilovich, M. G.; Reichle, R.; Wargan, K.; Coy, L.; Cullather, R.; Draper, C.; Akella, S.; Buchard, V.; Conaty, A.; da Silva, A. M.; Gu, W.; Kim, G.-K.; Koster, R.; Lucchesi, R.; Merkova, D.; Nielsen, J. E.; Partyka, G.; Pawson, S.; Putman, W.; Rienecker, M.; Schubert, S. D.; Sienkiewicz, M.; Zhao, B. The Modern-Era Retrospective Analysis for Research and Applications, Version 2 (MERRA-2). J. Clim. 2017, 30 (14), 5419-5454.

(76) Damian, V.; Sandu, A.; Damian, M.; Potra, F.; Carmichael, G. R. The Kinetic Preprocessor KPP - - A Software Environment for Solving Chemical Kinetics. Comput. Chem. Eng. 2002, 26 (11), 15671579.

(77) Eastham, S. D.; Weisenstein, D. K.; Barrett, S. R. H. Development and Evaluation of the Unified Tropospheric-Stratospheric Chemistry Extension (UCX) for the Global ChemistryTransport Model GEOS-Chem. Atmos. Environ. 2014, 89, 52-63.

(78) Pai, S. J.; Heald, C. L.; Pierce, J. R.; Farina, S. C.; Marais, E. A.; Jimenez, J. L.; Campuzano-Jost, P.; Nault, B. A.; Middlebrook, A. M.; Coe, H.; Shilling, J. E.; Bahreini, R.; Dingle, J. H.; Vu, K. An Evaluation of Global Organic Aerosol Schemes Using Airborne Observations. Atmos. Chem. Phys. 2020, 20 (5), 2637-2665.

(79) McDuffie, E. E.; Martin, R. V.; Spadaro, J. V.; Burnett, R.; Smith, S. J.; O’Rourke, P.; Hammer, M. S.; van Donkelaar, A.; Bindle, L.; Shah, V.; Jaeglé, L.; Luo, G.; Yu, F.; Adeniran, J. A.; Lin, J.; Brauer, M. Source Sector and Fuel Contributions to Ambient PM2.5 and Attributable Mortality across Multiple Spatial Scales. Nat. Commun. 2021, 12 (1), 3594

(80) Schmidt, J. A.; Jacob, D. J.; Horowitz, H. M.; Hu, L.; Sherwen, T.; Evans, M. J.; Liang, Q.; Suleiman, R. M.; Oram, D. E.; Le Breton, M.; Percival, C. J.; Wang, S.; Dix, B.; Volkamer, R. Modeling the Observed Tropospheric BrO Background: Importance of Multiphase Chemistry and Implications for Ozone, $\mathrm{OH}$, and Mercury. J. Geophys. Res.: Atmos. 2016, 121 (19), 11,819-11,835.

(81) Chen, Q.; Schmidt, J. A.; Shah, V.; Jaeglé, L.; Sherwen, T.; Alexander, B. Sulfate Production by Reactive Bromine: Implications for the Global Sulfur and Reactive Bromine Budgets. Geophys. Res. Lett. 2017, 44 (13), 7069-7078.

(82) Zhu, L.; Jacob, D. J.; Eastham, S. D.; Sulprizio, M. P.; Wang, X.; Sherwen, T.; Evans, M. J.; Chen, Q.; Alexander, B.; Koenig, T. K.; Volkamer, R.; Huey, L. G.; Le Breton, M.; Bannan, T. J.; Percival, C. J. Effect of Sea Salt Aerosol on Tropospheric Bromine Chemistry. Atmos. Chem. Phys. 2019, 19 (9), 6497-6507.
(83) Fisher, J. A.; Jacob, D. J.; Soerensen, A. L.; Amos, H. M.; Steffen, A.; Sunderland, E. M. Riverine Source of Arctic Ocean Mercury Inferred from Atmospheric Observations. Nat. Geosci. 2012, 5 (7), 499-504.

(84) Schwartz, S. E. Mass-Transport Considerations Pertinent to Aqueous Phase Reactions of Gases in Liquid-Water Clouds. In Chemistry of Multiphase Atmospheric Systems; Jaeschke, W., Ed.; Springer Berlin Heidelberg: Berlin, Heidelberg, 1986; pp 415-471. DOI: $10.1007 / 978-3-642-70627-116$.

(85) Jacob, D. Heterogeneous Chemistry and Tropospheric Ozone. Atmos. Environ. 2000, 34 (12-14), 2131-2159.

(86) Davidovits, P.; Kolb, C. E.; Williams, L. R.; Jayne, J. T.; Worsnop, D. R. Mass Accommodation and Chemical Reactions at Gas-Liquid Interfaces. Chem. Rev. 2006, 106 (4), 1323-1354.

(87) Holmes, C. D.; Bertram, T. H.; Confer, K. L.; Graham, K. A.; Ronan, A. C.; Wirks, C. K.; Shah, V. The Role of Clouds in the Tropospheric NO ${ }_{x}$ Cycle: A New Modeling Approach for Cloud Chemistry and Its Global Implications. Geophys. Res. Lett. 2019, 46 (9), 4980-4990.

(88) Fernandez, R. P.; Salawitch, R. J.; Kinnison, D. E.; Lamarque, J.F.; Saiz-Lopez, A. Bromine Partitioning in the Tropical Tropopause Layer: Implications for Stratospheric Injection. Atmos. Chem. Phys. 2014, 14 (24), 13391-13410.

(89) Saiz-Lopez, A.; Fernandez, R. P. On the Formation of Tropical Rings of Atomic Halogens: Causes and Implications. Geophys. Res. Lett. 2016, 43 (6), 2928-2935.

(90) Gabay, M.; Raveh-Rubin, S.; Peleg, M.; Fredj, E.; Tas, E. Is Oxidation of Atmospheric Mercury Controlled by Different Mechanisms in the Polluted Continental Boundary Layer vs. Remote Marine Boundary Layer? Environ. Res. Lett. 2020, 15 (6), 064026.

(91) Talbot, R.; Mao, H.; Scheuer, E.; Dibb, J.; Avery, M.; Browell, E.; Sachse, G.; Vay, S.; Blake, D.; Huey, G.; Fuelberg, H. Factors Influencing the Large-Scale Distribution of $\mathrm{Hg}^{\circ}$ in the Mexico City Area and over the North Pacific. Atmos. Chem. Phys. 2008, 8 (7), 2103-2114.

(92) Mao, H.; Talbot, R. W.; Sive, B. C.; Youn Kim, S.; Blake, D. R.; Weinheimer, A. J. Arctic Mercury Depletion and Its Quantitative Link with Halogens. J. Atmos. Chem. 2010, 65 (2-3), 145-170.

(93) Slemr, F.; Weigelt, A.; Ebinghaus, R.; Bieser, J.; Brenninkmeijer, C. A. M.; Rauthe-Schöch, A.; Hermann, M.; Martinsson, B. G.; van Velthoven, P.; Bönisch, H.; Neumaier, M.; Zahn, A.; Ziereis, H. Mercury Distribution in the Upper Troposphere and Lowermost Stratosphere According to Measurements by the IAGOS-CARIBIC Observatory: 2014-2016. Atmos. Chem. Phys. 2018, 18 (16), 1232912343.

(94) Stanevich, I.; Jones, D. B. A.; Strong, K.; Parker, R. J.; Boesch, H.; Wunch, D.; Notholt, J.; Petri, C.; Warneke, T.; Sussmann, R.; Schneider, M.; Hase, F.; Kivi, R.; Deutscher, N. M.; Velazco, V. A.; Walker, K. A.; Deng, F. Characterizing Model Errors in Chemical Transport Modeling of Methane: Impact of Model Resolution in Versions v9-02 of GEOS-Chem and V35j of Its Adjoint Model. Geosci. Model Dev. 2020, 13 (9), 3839-3862.

(95) Steffen, A.; Douglas, T.; Amyot, M.; Ariya, P.; Aspmo, K.; Berg, T.; Bottenheim, J.; Brooks, S.; Cobbett, F.; Dastoor, A.; Dommergue, A.; Ebinghaus, R.; Ferrari, C.; Gardfeldt, K.; Goodsite, M. E.; Lean, D.; Poulain, A. J.; Scherz, C.; Skov, H.; Sommar, J.; Temme, C. A Synthesis of Atmospheric Mercury Depletion Event Chemistry in the Atmosphere and Snow. Atmos. Chem. Phys. 2008, 8 (6), 1445-1482.

(96) Selin, N. E.; Jacob, D. J. Seasonal and Spatial Patterns of Mercury Wet Deposition in the United States: Constraints on the Contribution from North American Anthropogenic Sources. Atmos. Environ. 2008, 42 (21), 5193-5204.

(97) Shah, V.; Jaeglé, L. Subtropical Subsidence and Surface Deposition of Oxidized Mercury Produced in the Free Troposphere. Atmos. Chem. Phys. 2017, 17 (14), 8999-9017.

(98) McClure, C. D.; Jaffe, D. A.; Edgerton, E. S. Evaluation of the $\mathrm{KCl}$ Denuder Method for Gaseous Oxidized Mercury Using $\mathrm{HgBr}_{2}$ at an In-Service AMNet Site. Environ. Sci. Technol. 2014, 48 (19), 11437-11444. 
(99) Gustin, M. S.; Dunham-Cheatham, S. M.; Zhang, L. Comparison of 4 Methods for Measurement of Reactive, Gaseous Oxidized, and Particulate Bound Mercury. Environ. Sci. Technol. 2019, 53 (24), 14489-14495.

(100) Liu, K.; Wu, Q.; Wang, L.; Wang, S.; Liu, T.; Ding, D.; Tang, Y.; Li, G.; Tian, H.; Duan, L.; Wang, X.; Fu, X.; Feng, X.; Hao, J. Measure-Specific Effectiveness of Air Pollution Control on China's Atmospheric Mercury Concentration and Deposition during 20132017. Environ. Sci. Technol. 2019, 53 (15), 8938-8946.

(101) Guentzel, J. L.; Landing, W. M.; Gill, G. A.; Pollman, C. D. Processes Influencing Rainfall Deposition of Mercury in Florida. Environ. Sci. Technol. 2001, 35 (5), 863-873.

(102) Zhang, Y.; Jaeglé, L.; van Donkelaar, A.; Martin, R. V.; Holmes, C. D.; Amos, H. M.; Wang, Q.; Talbot, R.; Artz, R.; Brooks, S.; Luke, W.; Holsen, T. M.; Felton, D.; Miller, E. K.; Perry, K. D.; Schmeltz, D.; Steffen, A.; Tordon, R.; Weiss-Penzias, P.; Zsolway, R. Nested-Grid Simulation of Mercury over North America. Atmos. Chem. Phys. 2012, 12 (14), 6095-6111.

(103) Holmes, C. D.; Krishnamurthy, N. P.; Caffrey, J. M.; Landing, W. M.; Edgerton, E. S.; Knapp, K. R.; Nair, U. S. Thunderstorms Increase Mercury Wet Deposition. Environ. Sci. Technol. 2016, 50 (17), 9343-9350.

(104) Sunderland, E. M.; Mason, R. P. Human Impacts on Open Ocean Mercury Concentrations. Global Biogeochem. Cycles 2007, 21 (4), GB4022.

(105) Mason, R. P.; Choi, A. L.; Fitzgerald, W. F.; Hammerschmidt, C. R.; Lamborg, C. H.; Soerensen, A. L.; Sunderland, E. M. Mercury Biogeochemical Cycling in the Ocean and Policy Implications. Environ. Res. 2012, 119, 101-117.

(106) Obrist, D.; Kirk, J. L.; Zhang, L.; Sunderland, E. M.; Jiskra, M.; Selin, N. E. A Review of Global Environmental Mercury Processes in Response to Human and Natural Perturbations: Changes of Emissions, Climate, and Land Use. Ambio 2018, 47 (2), 116-140.

(107) Jiskra, M.; Sonke, J. E.; Obrist, D.; Bieser, J.; Ebinghaus, R.; Myhre, C. L.; Pfaffhuber, K. A.; Wängberg, I.; Kyllönen, K.; Worthy, D.; Martin, L. G.; Labuschagne, C.; Mkololo, T.; Ramonet, M.; Magand, O.; Dommergue, A. A Vegetation Control on Seasonal Variations in Global Atmospheric Mercury Concentrations. Nat. Geosci. 2018, 11 (4), 244-250.

(108) Sun, G.; Sommar, J.; Feng, X.; Lin, C.-J.; Ge, M.; Wang, W.; Yin, R.; Fu, X.; Shang, L. Mass-Dependent and -Independent Fractionation of Mercury Isotope during Gas-Phase Oxidation of Elemental Mercury Vapor by Atomic $\mathrm{Cl}$ and Br. Environ. Sci. Technol. 2016, 50 (17), 9232-9241.

(109) Ariya, P. A.; Peterson, K. A. Chemical Transformation of Gaseous Elemental Hg in the Atmosphere. In Dynamics of Mercury Pollution on Regional and Global Scales; Pirrone, N., Mahaffey, K. R., Eds.; Springer-Verlag: New York, 2005; pp 261-294. DOI: 10.1007/ 0-387-24494-8_12.

(110) Holmes, C. D.; Prather, M. J.; Søvde, O. A.; Myhre, G. Future Methane, Hydroxyl, and Their Uncertainties: Key Climate and Emission Parameters for Future Predictions. Atmos. Chem. Phys. 2013, 13 (1), 285-302.

(111) Wilcox, J. A Kinetic Investigation of High-Temperature Mercury Oxidation by Chlorine. J. Phys. Chem. A 2009, 113 (24), 6633-6639.

(112) Wild, O.; Prather, M. J. Excitation of the Primary Tropospheric Chemical Mode in a Global Three-Dimensional Model. J. Geophys. Res. 2000, 105 (D20), 24647-24660.

(113) Strömberg, D.; Gropen, O.; Wahlgren, U. Non-Relativistic and Relativistic Calculations on Some $\mathrm{Zn}, \mathrm{Cd}$ and $\mathrm{Hg}$ Complexes. Chem. Phys. 1989, 133 (2), 207-219.

(114) AMAP/UNEP. Technical Background Report for the Global Mercury Assessment 2018; Arctic Monitoring and Assessment Programme, Oslo, Norway/UN Environment Programme, Chemicals and Health Branch, Geneva, Switzerland., 2019.

(115) Sprovieri, F.; Pirrone, N.; Bencardino, M.; D’Amore, F.; Angot, H.; Barbante, C.; Brunke, E.-G.; Arcega-Cabrera, F.; Cairns, W.; Comero, S.; Diéguez, M. del C.; Dommergue, A.; Ebinghaus, R.;
Feng, X. B.; Fu, X.; Garcia, P. E.; Gawlik, B. M.; Hageström, U.; Hansson, K.; Horvat, M.; Kotnik, J.; Labuschagne, C.; Magand, O.; Martin, L.; Mashyanov, N.; Mkololo, T.; Munthe, J.; Obolkin, V.; Ramirez Islas, M.; Sena, F.; Somerset, V.; Spandow, P.; Vardè, M.; Walters, C.; Wängberg, I.; Weigelt, A.; Yang, X.; Zhang, H. Five-Year Records of Mercury Wet Deposition Flux at GMOS Sites in the Northern and Southern Hemispheres. Atmos. Chem. Phys. 2017, 17 (4), 2689-2708.

(116) Fu, X.; Yang, X.; Lang, X.; Zhou, J.; Zhang, H.; Yu, B.; Yan, H.; Lin, C.-J.; Feng, X. Atmospheric Wet and Litterfall Mercury Deposition at Urban and Rural Sites in China. Atmos. Chem. Phys. 2016, 16 (18), 11547-11562. 